\section{InI)ret}

3.2020

Hadeel Al Sharqawi

IE University

\title{
Reforming the U.S Stockholding and Voting Systems
}

\section{Sumario}

La introducción del sistema de tenencia indirecta ("IHS") en Estados Unidos causó serias ineficiencias en la votación de los accionistas. El sistema de acciones ya no podía rastrear la propiedad de acciones a ningún accionista en particular. Esto desencadenó una serie de cambios legales, entre ellos la creación de un sistema de votación por poder mediante el cual los derechos de voto se transfieren del depositario de seguridad central ("CSD"), a los corredores de bolsa, bancos y otros tipos de intermediarios en el IHS hasta llegar a los accionistas. La complejidad del procedimiento y la opacidad del hecho de propiedad producen patologías de votación que socavan la integridad del mecanismo. Sin embargo, blockchain ofrece una solución revolucionaria: permite el seguimiento de la propiedad de acciones a accionistas anteriores $y$, por lo tanto, promete mitigar o eliminar dichas patologías de votación. No obstante, la adopción sigue dependiendo en gran medida de resolver las brechas regulatorias actuales y problemas de diseño técnico.

\begin{abstract}
The introduction of the indirect holding system ("IHS") in the US caused serious inefficiencies to shareholder voting. The stockholding system could no longer trace share ownership to any particular shareholder. This triggered a series of legal changes, among them the creation of a proxy voting system where voting rights are passed from the central security depository ("CSD"), to brokers/ banks, and other types of intermediaries in the IHS all the way to shareholders. Procedural complexity and ownership opacity yield voting pathologies that undermine the integrity of the voting mechanism. However, blockchain offers a revolutionary solution. It enables the tracing of share ownership to former and current shareholders, and thus, promises to mitigate or eliminate voting pathologies. Notwithstanding, adoption remains largely contingent on resolving current regulatory gaps and technical design issues.
\end{abstract}

Título: Reforma de los sistemas de votación y retención de acciones en los Estados Unidos

Keywords: indirect holding system, voting pathalogies, blockchain.

Palabras clave: sistema de retención indirecta, patologías de votación, blockchain.

DOI: $10.31009 /$ InDret.2020.i3.14 


\section{InDret}

3.2020

Received

04/04/2020

Accepted

06/09/2020
Index

I. Introduction

II. The U.S Stockholding \& Voting Systems

1. Moving from a Direct to an Indirect Holding System

2. Ownership

2.1 How Nominee Shares Are Owned

2.1.1 Agreement or Due Care Formulation

2.2 Misalignments with Delaware Corporate Law

3 Corporate Voting

3.1 How Nominee Shares Are Voted

3.2 Inefficiencies of Proxy Voting

4. Pathologies of Shareholder Voting

4.1 Pathologies of Complexity

4.2 Pathologies of Ownership

4.3 Pathologies of Misalignment

4.4 Financial Costs

III. A Potential Solution: Blockchain

1. Blockchain Trends

2. What is Blockchain

2.1 Distributed Ledgers

2.2 Cryptography

3. Overhaul of Existing CSPs

3.1 Envisioning CSPs on Blockchain

3.2 Technical Design Issues

3.3 Regulatory Gap

4 Overhaul of Existing Proxy Voting System

4.1 Envisioning Proxy Voting on Blockchain

4.2 Impact on Shareholder Voting

4.2.1 Pathologies of Complexity

4.2.2 Pathologies of Ownership

4.2.3 Pathologies of Misalignment

4.2.4 Financial Costs

IV. Conclusion

Este trabajo se publica con una licencia Creative Commons Reconocimiento-No Comercial 4.0 Internacional @) (1) ( ) 


\section{Introduction*}

Theory of corporate law is premised on the consideration that shareholders are owners of a corporation, and control it by exercising their voting rights. Unfortunately, modern shareholder voting is broken. The current US voting system was not created through intentional architecture, but through necessity of accommodating a sudden transition from direct to indirect holding of securities.

For publicly listed corporations in the US, paper certificated transfers were highly inefficient and eventually triggered a crisis in the 1970s that necessitated the emergence of a CSD and clearing agency known as, Depository and Trust Company ("DTC”). The DTC keeps physical possession of most stock certificates, serves as the record owner for these shares, and clears and settles trades by transferring beneficial ownership of shares registered in book-entry form from seller to buyer.

However, this holding system meant that corporations lost traceability of beneficial (or true) owners. Because certificates are kept in fungible bulks it is impossible to specify who owns any given share of stock. Put differently, we no longer say that 'investor A' is the beneficial owner of stock certificate \#123456789 instead she owns one share from a pool of interchangeable certificates. When A sells the stock, DTC does not link that specific share to one of the thousands of shares traded by other buyers that same day.

Indeed, this approach resolved an urgent crisis but the lack of traceability broke communication between the corporation and shareholders. New regulatory requirements and market practices emerged to rekindle communication by passing proxies or voting instructions back and forth from the record owner (DTC) to beneficial owners (shareholders) along a series of intermediaries. However, this voting system causes several pathologies - the costs of which burden shareholders and raise concerns about voting accuracy, transparency, and trustworthiness.

We delve, particularly, into the voting pathologies that are experienced by shareholders of a Delaware company listed on the New York Stock Exchange ("NYSE"). There is abundant literature on how such shareholders endure the inability to ascertain how their shares are voted despite being a perquisite for certain legal rights under corporate law (e.g. appraisal claims); the opacity of ownership that leads to over-voting in the context of stock loans; and the untraceable shares that are exploited by savvy investors routinely manipulating the system (e.g. through hedging) for personal profit.

As the voting system is built around untraceable shares, only incremental changes have been made till today to improve shareholder voting. However, the financial market has reached an interesting juncture at which blockchain could enable the tracing of share ownership throughout the settlement cycle. DTC would no longer serve as the record owner, nor hold shares in unidentifiable bulk. As some authors put it, blockchain offers an avenue for a direct holding system. ${ }^{1}$

\footnotetext{
* Autor de contacto: Hadeel Al Sharqawi, Sharqawi.hadeel@gmail.com.

${ }^{1}$ Charles W Mooney Jr, 'Beyond Intermediation: A New (FinTech) Model for Securities Holding Infrastructures' (2019) University of Pennsylvania Law School 2098.
} 
It follows that this contribution aims to examine: how the implementation of blockchain in the US stockholding and voting systems may impact shareholder voting. Blockchain promises to mitigate (or eliminate) voting pathologies - restoring accuracy, transparency, and trust in the voting system. However, the degree of impact depends, in part, on the choice of blockchain components and the method of implementation. This contribution suggests that a private permissioned blockchain is more appropriate than a public permissionless blockchain, given the economics of stockholding and voting systems. This view does not constitute an evangelization of a particular form of blockchain (nor of the technology itself).

To date, the concept of facilitating blockchain plumbing and/ or voting has been well received by corporate law. ${ }^{2}$ However, the claims and predictions that blockchain will bring profound improvements reflect more hype than actual happenings. Proponents seem to overlook regulatory gaps and technical design issues which may preclude adoption. Further investigation into the matter has, conversely, lead us to reason that a blockchain solution remains theoretical unless regulatory gaps at federal and/ or state level; and technical design issues are resolved.

Formulating this reasoning involved (i) a purely technical study of blockchain's technological benefits/ challenges; and (ii) an examination of its functional and legal benefits/ risks for shareholders in the context of stockholding and voting. These considerations offered by literature are often either extreme or neutral. Thus, a pooling of these considerations allowed the formulation of a clearer multi-angled analysis of whether blockchain fits into the existing financial and legal infrastructure; and whether benefits and risks to shareholders are overstated or understated. Consequently, we endeavor to build a blockchain structure based on these multi-angled considerations.

Apart from varying extremities, varying blockchain components and models offered by extant literature meant different outcomes in terms of holding and voting. Thus, this contribution took inspiration of one single proposal made by the Council of Institutional Investors, ${ }^{3}$ and thereafter appropriated elements suggested by other sources. In turn, the proposed blockchain infrastructure goes beyond the basic framework that is often described by extant literature. At the same time, this paper makes connections and comparisons between current holding/ voting systems and the proposed one in order to draw one's attention to novelty elements and remind the reader of faults within the IHS.

Moreover, an investigation into the subject matter was done by using an array of primary and secondary sources. The different layers of primary sources used reflect the interdependencies existent between stockholding and voting systems, at state and federal level. We rely on legislations including Delaware General Corporate Law ("DGCL”), Delaware's Uniform Commercial Code (“UCC”), and the federal

\footnotetext{
${ }^{2}$ Ibid.

3 Council of Institutional Investors, 'Re: File Number 4-725 Roundtable on the Proxy Process' (Council of Institutional Investors 31 January 2019) 9 <www.sec.gov/comments/4-725/4725-4864575-177347.pdf> accessed 29 November 2019 (CII Letter 31 Jan 2019); Council of Institutional Investors, 'Re: File Number 4-725 Roundtable on the Proxy Process, and File Number S7-24-16 (Universal Proxy)' (Council of Institutional Investors 8 November 2018) 4 <www.cii.org/files/20181108\%20CII\%20Letter\%20for\%20SEC\%20Proxy\%20Roundtable.pdf> accessed 29 November 2019 (CII Letter 8 Nov 2018).
} 
Securities Act of 1933 (“SEC Rules”). We also utilize US Securities and Exchange Commission (“SEC”) releases - these are not positive law but are highly persuasive. Further, case law of Delaware's Chancery Court is used. For secondary sources we rely on SEC roundtables; proposals by Council of Institutional Investors to SEC; a seminal speech by Delaware's Vice Chancellor; white papers by renewed institutions; and a range of scholarly articles.

We layout our analysis as follows: Section II examines the evolution of the IHS and share ownership starting from the 1970s paper crisis; highlights the incompatibility between property rights under UCC and DGCL; and examines the unfavorable impact therefrom. The section then moves to the voting system, analyzing several voting pathologies and how they stem from procedural complexities of the voting process, and IHS conflicts with the core ideal of company ownership and shareholder voting.

Section III surveys recent blockchain trends in the financial market, and explains foundational concepts underpinning the technology - whilst minimizing programming jargon. It also demonstrates how blockchain clearing and settlement might address inefficiencies, and bring the reality of share registration back in line with its intended operation. However, this consideration is challenged by technical design issues and regulatory gaps - but we offset the latter issue by a proposal for regulatory relief under SEC Rules. The section moves to explain how blockchain voting operates, and how that might remedy voting pathologies in favor of greater transparency and trust. It would have been interesting to gauge how such reforms may further impact corporate governance. However, we forgo such analysis to preserve consistency and maintain focus on the plumbing and voting systems. Finally, we summarize the contribution with a brief conclusion.

\section{The U.S Stockholding \& Voting Systems}

\section{Moving from a Direct to an Indirect Holding System}

Traditionally, all US corporate statutes provided for the issuance of registered shares, as opposed to bearer shares, in which each share of stock was registered as belonging to a specific person(s) on a corporation's books. ${ }^{4}$ Particularly, DGCL deemed (and continues to deem) shareholders as persons who are, as of the record date, listed as registered owners on an issuer's books. ${ }^{5}$ Only record holders in their capacity as shareholders are entitled to, notice of the shareholder meeting and voting. At that time, the holding system enabled issuers to deal directly with their investors when dividends or interest was paid, or even when the company merged. ${ }^{6}$ However, standard practices known to the financial market for hundreds of years are no longer standard and do not represent the reality of publicly listed corporations in the US today.

\footnotetext{
${ }^{4}$ David Donald, 'The Rise and Effects of the Indirect Holding System: How Corporate America Ceded its Shareholders to its Intermediaries' (2007) University of Frankfurt Institute for Law and Finance Draft Paper 1017206, 5 <file://C:/Users/User/Downloads/SSRN-id1017206.pdf> accessed 29 November 2019.

${ }^{5}$ Del. Code Ann. tit. 8, § 219 (West).

${ }^{6}$ Alexander Daniels, 'Blockchain \& Shareholder Voting: A Hard Fork for 21 ${ }^{\text {st }}$ Century Corporate Governance' [2018] 21 University of Pennsylvania Journal of Business Law 405, 414; Joseph L Bower and Lynn S Paine, The Error at the Heart of Corporate Leadership (Harvard Business School Publishing Corporation 2017) 166.
} 
Transfer of ownership (or settlement) ${ }^{7}$ of registered securities beginning in the $17^{\text {th }}$ century until the late 1960s depended on paper. For each trade to settle, someone working for the exchange had to receive a physical certificate (representing a share of stock) from the issuer, reregister the name of the buyer, and reissue a new certificate and deliver it to the buyer. ${ }^{8}$ Only when the buyer takes possession of the physical certificate does the trade settle, and she becomes the new owner. This worked well for centuries (e.g. one upside was that ownership was definite and tangible) ${ }^{9}$ until the paperwork crises hit Wall street. ${ }^{10}$ With spiking trade volumes, paper-based ownership became untenable. ${ }^{11}$ As such, US Congress ordered immobilization of registered shares at CSD. ${ }^{12}$

Immobilization meant that issuers deposit share certificates at $\mathrm{DTC}^{13}$ which in turn, settles and clears transactions electronically between sellers and buyers in book-entry form. ${ }^{14}$ An investor does not maintain an account with DTC, albeit another layer of intermediaries comprising of brokers/ banks registered with DTC hold securities in favor of investors through accounts maintained by DTC. ${ }^{15}$ Under this paradigm, an investor's name is listed on a broker/ bank's books as beneficial owner of the securities; a bank/ broker's name is recorded on DTC's ownership records; and DTC's nominee name (“Cede") is listed as the registered owner with the issuer or (their transfer agent). ${ }^{16}$ When a retail investor sells a stock held in nominee name, shares are debited electronically from her broker's account at DTC, and credited from the buying broker's DTC account. ${ }^{17}$ Similarly, brokers update their books to reflect the sale/ purchase transaction on the seller/ buyer's accounts, respectively. As for the issuer's shareholder list, it remains unchanged under the name of Cede. In effect, immobilization isolated issuers from the trading and tracking process, leaving DTC and its participants to coordinate communication with beneficial owners. ${ }^{18}$

${ }^{7}$ David Donald, 'Heart of Darkness: The Problem at The Core of the US Proxy System and Its Solution' [2011] 6 Virginia Law \& Business Review Association 41, 45.

8 Peter Greco, ‘Blockchain Implementation in Today's Security Settlement Process' (2018) 6 $<$ https://thedailycpa.com/wp-content/uploads/2019/05/Blockchain-Implementation-in-Todays-Security-

Settlement-Process-2.pdf> accessed 29 November 2019.

${ }^{9}$ Daniels, 'Blockchain \& Shareholder Voting' (n 6) 10.

${ }^{10}$ Donald, 'The Rise and Effects of the Indirect Holding System' (n 4) 11.

${ }^{11}$ Unsafe \& Unsound Practices of Sec. Indus., Release No. 9434 (Dec. 28, 1971).

1215 U.S.C.A. § 78q-1(e) (West).

${ }^{13}$ DTC is a subsidiary of the Depository and Trust Clearing Corporation ("DTCC"). It is registered with the Securities and Exchange Commission ("SEC") as a clearing agency, and is subject to SEC regulation. DTC provides clearing, settlement and central securities depository services for trades in eligible securities. See Depository and Trust Clearing Corporation, 'The Depository Trust Company' (Depository and Trust Clearing Corporation, 29 November 2019) <www.dtcc.com/about/businesses-and-subsidiaries/dtc> accessed 27 November 2019.

1415 U.S.C.A. § 78q-1(e) (West).

${ }^{15}$ Larry T Garvin, 'The Changed (and Changing) Uniform Commercial Code' (1999) 26 Florida State University Law Review 285, 315.

${ }^{16}$ Ibid.

${ }^{17}$ Notably, banks/ brokers holding securities in nominee name or otherwise on behalf of a beneficial owner are described by SEC Rules as entities that exercise "fiduciary powers". See 17 C.F.R. § 240.14c-1(c).

${ }^{18}$ Virginia B Morris and Stuart Z Glodstein, The Lifecycle of a Security (Lightbulb Press, Inc. 2010) 10. 


\section{Ownership}

\subsection{How Nominee Shares Are Owned}

The move from a direct to an IHS necessitated that the law governing property rights vis-à-vis securities be amended to accommodate the emergence of custodians (see figure 1). ${ }^{19}$ The revised Article 8 of Delaware's UCC defines an entitlement holder ${ }^{20}$ as a person having a security entitlement to a financial asset $^{21}$ (security) against its securities intermediary ${ }^{22}$ (DTC, brokers, and banks). Reading Article 8 in light of the above, one can reaffirm that DTC holds securities directly in its capacity as the registered owner, while banks/ brokers who have possession (custody) of securities hold them indirectly as security entitlements. Similarly, beneficial owners ${ }^{23}$ holding securities indirectly through their banks/ brokers also have security entitlements in the financial asset. Consideration must be given to the fact that banks/ brokers are entitlement holders when they are registered DTC members holding securities through DTC; or non-DTC members holding securities in a securities account with intermediaries who are DTC members. ${ }^{24}$

Moreover, an entitlement holder as a 'purchaser' of a security has 'rights' and 'property interests' deriving from a security entitlement. ${ }^{25}$ Article 8 limits the nature and scope of such property interests to those rights enumerated in section 8-503. Subsection 503(a) provides that an entitlement holder has a superior claim in a security against the intermediary's general creditors ${ }^{26}$ - albeit such claim is inferior vis-à-vis secured creditors. ${ }^{27}$ In doing so, UCC attempts to protect the entitlement holder, primarily the beneficial owner, from systemic risk and failed transactions. ${ }^{28}$ Subsection 503(b) then describes a security entitlement as a pro rata interest in a fungible (interchangeable) pool of a particular security. That interest, however, should not be confused with a claim to a specific asset held by the intermediary. ${ }^{29}$

Consider, a hypothetical situation where Harvard endowment owns 100 shares of IBM stock through JP Morgan Chase which holds 100,000 shares of IBM stock in its DTC account (see figure 1).$^{30}$ It follows that, JP Morgan Chase will match Harvard endowment's holding with a particular interest rather than with a

${ }^{19}$ Del. Code Ann. tit. 6 tit. 6, Subt. I, art. 8, Refs \& Annos (West).

${ }^{20}$ Del. Code Ann. tit. 6, § 8-102(a)(7) (West).

${ }^{21}$ Del. Code Ann. tit. 6, § 8-102(a)(9)(i) (West).

${ }^{22}$ Del. Code Ann. tit. 6, § 8-501(b)(1) (West)

2317 C.F.R. § $240.13 d-3$.

${ }^{24}$ Russell A Hakes, 'UCC Article 8: Will the Indirect Holding of Securities Survive the Light of Day' [2002] 35 Loyola of Los Angeles Law Review 661, 685-686.

${ }^{25}$ Ibid 686-687.

${ }^{26}$ Del. Code Ann. tit. 6, § 8-503(a) (West).

${ }^{27}$ Del. Code Ann. tit. 6, § 8-511 (West).

${ }^{28}$ Hakes (n 24) 688.

${ }^{29}$ Del. Code Ann. tit. 6, § 8-104 (West); Del. Code Ann. tit. 6, § 8-503(a) (West)

${ }^{30}$ Marcel Kahan and Edward Rock, 'The Hanging Chads of Corporate Voting' [2008] 96 The Georgetown Law Journal 1227, 1240-1243. 
particular share of stock, ${ }^{31}$ corresponding to 0.001 interest in each share of IBM stock. While JP Morgan records how its 100,000 shares of IBM stock are allocated among its institutional investors (e.g. Harvard endowment), other custodians in the chain (including DTC) have no way of knowing that the entitlement holder (e.g. Harvard endowment) has an interest in the security. ${ }^{32}$ Evidently, commingling securities in a fungible bulk obscures the identity of the ultimate entitlement holder (i.e. beneficial owner) and the quantity owned by her. ${ }^{33}$ This lack of transparency is aggravated by the fact that, an investor becomes an entitlement holder once securities are credited to her account, ${ }^{34}$ without regard to whether her intermediary has acquired the shares to be credited or whether it owns a single share of that stock. ${ }^{35}$ It is worth noting, that defects of this nominee or fungible bulk system come to the fore in the misalignment of property rights and over-voting. ${ }^{36}$

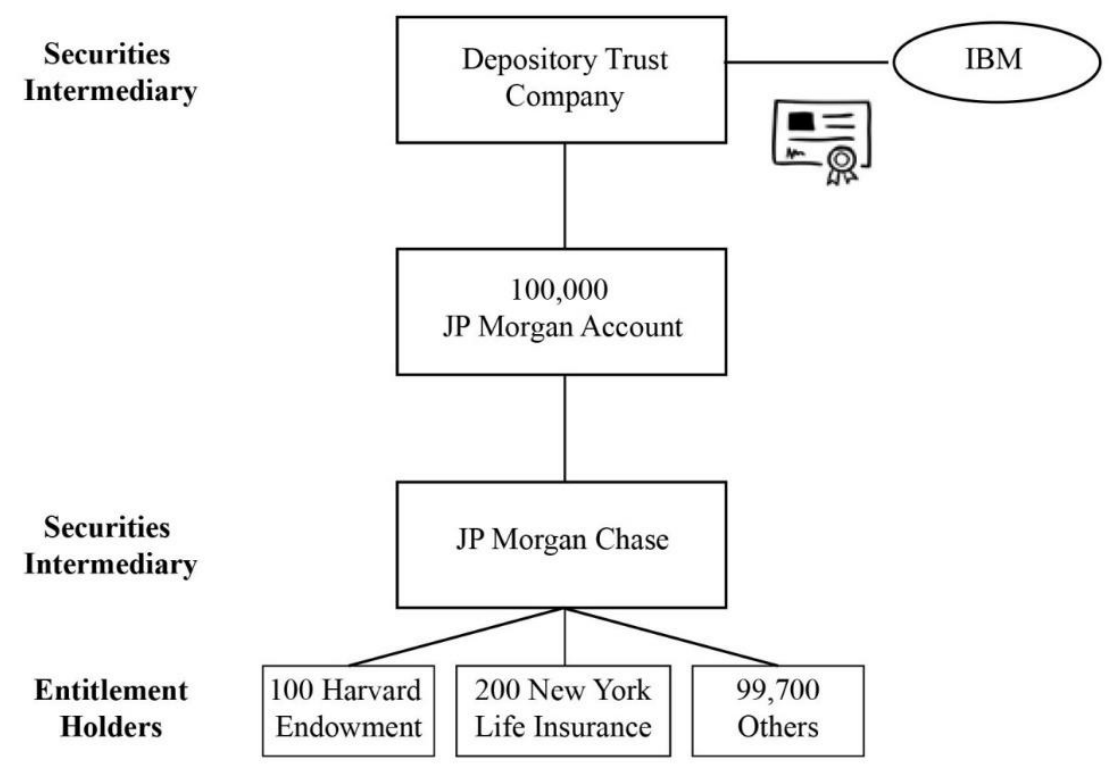

Figure 1: How Nominee Shares are owned

Subsection 8-503(c) limits the enforcement of a property interest to specific rights conferred against a securities intermediary. ${ }^{37}$ That is, the rights which an entitlement holder may enforce against the

${ }^{31}$ US Securities and Exchange Commission, 'Roundtable on Proxy Voting Mechanics' (Topic on Share Ownership and Voting, Washington DC, May 2007) <www.sec.gov/spotlight/proxyprocess/proxyvotingbrief.htm>accessed 27 November 2019.

32 George Geis, ‘Traceable Shares and Corporate Law' (2018) 113 Northwestern University Law Review 1, 7-8 (forthcoming).

33 Spencer J Nord, ‘Blockchain Plumbing: A Potential Solution for Shareholder Voting’ [2019] 21 University of Pennsylvania Journal of Business Law 706, 714-715.

${ }^{34}$ Del. Code Ann. tit. 6, § 8-501(c) (West)

${ }^{35}$ Kahan and Rock (n 30) 1242.

${ }^{36}$ Ibid 1242-1243.

${ }^{37}$ Hakes (n 24) 692-696 
securities intermediary are only those pertaining to an intermediary's obligations towards the entitlement holder (statutory obligations and performance duties). ${ }^{38}$ Namely, an intermediary is obligated to obtain and pass on to the entitlement holder dividends paid out by the corporation; and exercise ownership rights attached to the security on behalf of the entitlement holder (e.g. right to vote or right to enforce legal obligations). ${ }^{39}$ Save for enforcement of a property interest against the immediate securities intermediary, enforcement against third parties becomes extremely limited. ${ }^{40}$ An entitlement holder does not have any rights against upper tier intermediaries or issuers. It is worth presaging that, governance rights are subverted when confronted with a complex corporate voting system. ${ }^{41}$

\subsubsection{Agreement or Due Care Formulation}

An intermediary performs its obligation to exercise ownership rights as a representative of the entitlement holder, rather than at its own discretion. Particularly, section 8-506 stipulates that an intermediary shall exercise ownership rights upon the direction of the entitlement holder. ${ }^{42}$ Importantly, this feature distinguishes a securities account from other arrangements where one person holds securities on behalf of another (e.g. the relationship between a mutual fund and its shareholders, or a trustee and its beneficiaries). Of course, this feature does not preclude the entitlement holder from conferring the intermediary with discretionary authority.

The performance of the aforesaid obligation is dependent upon the agreement/due care formulation under subsections 8-506(1) and (2). Subsection 8-506(1) provides that an intermediary conforms to the aforesaid obligation if it acts in accordance to an agreement ${ }^{43}$ promulgated between it and the entitlement holder, whereby the general statutory and contractual duty of good faith limits performance. ${ }^{44}$ For instance, if an agreement stipulates that the intermediary assumes no responsibility for the safekeeping of the entitlement holder's securities positions then that conflicts with the duty of good faith.

However, if no agreement specifies the details of the relevant obligation then subsection 8-506(2) provides that the obligation to preform ownership rights is satisfied if the intermediary exercises due care in accordance to reasonable commercial standards. ${ }^{45}$ The duty of care encompasses both care in the intermediary's own operations and care in the selection of other subsequent intermediaries through which the intermediary holds securities. The duty of care also incorporates principles of common law/case law under which the specific actions or precautionary measures necessary to the duty of due care are determined by aspects such as the nature and value of the property, the practices and customs of

\footnotetext{
${ }^{38}$ Del. Code Ann. tit. 6, § 8-503(c) (West).

39 Christoph Van der Elst and Anne Lafarre, 'Blockchain and Smart Contracting for the Shareholder Community' (2019) $20 \quad$ European $\quad$ Business $\quad$ Organization Law $\quad$ Review <https://ink.springer.com/content/pdf/10.1007\%2Fs40804-019-00136-0.pdf> accessed 27 November 2019.

${ }^{40}$ Hakes (n 24) 689.

${ }^{41}$ Kahan and Rock (n 30) 1243.

${ }^{42}$ Del. Code Ann. tit. 6, § 8-506 (West).

${ }^{43}$ Del. Code Ann. tit. 6, § 8-506(1) (West).

${ }^{44}$ See Del. Code Ann. tit. 6, § 1-201 (West).

${ }^{45}$ Del. Code Ann. tit. 6, § 8-506(2) (West).
} 
the business, inter alia. ${ }^{46}$ Alternatively, subsection 8-506(2) provides that the intermediary satisfies the relevant obligation if it places the entitlement holder in a position to exercise the rights directly. ${ }^{47}$

On the other hand, the obligation to pass over economic benefits is the only obligation upon the intermediary that is not subject to limitations by agreement or due care. ${ }^{48}$ Section $8-509$ (a) explicitly states that compliance with regulatory law (i.e. securities law enacted by SEC) by an intermediary constitutes compliance with the obligation to pass economic benefits (section 8-505), and to perform ownership rights on behalf of entitlement holders (section 8-506) among other statutory obligations under Delaware UCC (e.g. obligation to obtain and maintain securities under section 8-504). ${ }^{49}$

\subsection{Misalignments with Delaware Corporate Law}

Subsection 1 highlighted how the introduction of immobilization was a welcome development in the 1970s. The financial market saw an increase in safety and efficiency of transactions as the risk of losing or misplacing share certificates was obviated; a reduction in counterparty risk by ensuring that payment and delivery of shares occur relatively simultaneously; and a boost in market liquidity by leveraging economies of scale at DTC. ${ }^{50}$ However, as Delaware Vice Chancellor puts it, the 'solution [...] was like Alexander cutting the Gordian Knot. It solved the immediate problem, but it created a lot of loose ends. ${ }^{51}$

One of those loose ends, is the mismatch between property rights presumed under UCC and DGCL. While Delaware tailored its commercial law to nominee shares, its corporate law maintained that shareholders directly own definite number of shares. ${ }^{52}$ Hence, the contradiction is twofold. First, recall that under a nominee system a shareholder does not own a determinate number of shares, albeit has a pro rate interest in a fungible pool of securities held with an intermediary (broker/ bank). ${ }^{53}$ Second, a beneficial owner

\footnotetext{
${ }^{46}$ Ronald J Mann and others, Comprehensive Commercial Law: 2017 Statutory Supplement (Wolters Kluwer Law \& Business, 2017).

${ }^{47}$ Del. Code Ann. tit. 6, § 8-506(2) (West).

${ }^{48}$ Del. Code Ann. tit. 6, § 8-505(b) (West).

${ }^{49}$ For instance, SEC Rule 17f-4 reflects the minimum standard of care that Article 8 demands in circumstances where intermediaries and entitlement holders have not agreed to a standard. Therein a mutual fund's securities intermediary is obligated, at minimum, to exercise due care based on reasonable commercial standards when preforming its obligations to obtain and maintain financial assets. See Del. Code Ann. tit. 6, § 8-504 (West); US Securities and Exchange Commission, 'Final Rule: Custody of Investment Company Assets with a Security Depository' (The SEC is adopting amendments to rule 17f-4 under the Investment Company Act of 1940, Washington DC, February 2003) <https://www.sec.gov/rules/final/ic-25934.htm\#I> accessed 28 June 2020.

${ }^{50}$ Federico Panisi and others, 'Blockchain and Public Companies: A Revolution in Share Ownership Transparency, Proxy-Voting and Corporate Governance?' [2019] 2.2 Stanford Journal of Blockchain Law and Policy 1, 8. See also Donald, 'Heart of Darkness' (n 7) 57

${ }^{51}$ J Travis Laster, 'The Block Chain Plunger: Using Technology to Clean Up Proxy Plumbing and Take Back the Vote' (Keynote Speech to the Fall 2016 meeting of the Council of Institutional Investors, 29 September 2016) 6 $<$ www.cii.org/files/0929_16_laster_remarks.pdf> accessed 27 November 2019.

52 Ibid.

${ }^{53}$ Morris and Glodstein (n 18) 9.
} 
does not own the security directly rather has an entitlement to the rights attached to the ownership of securities (e.g. voting)..$^{54}$

Internal faults also appeared within DGCL upon the emergence of the nominee system. Placing Cede as the only registered owner, effectively eliminated the stockholder list that was meant to facilitate communication between issuers and shareholders, and among shareholders themselves. Shareholders became distanced from the corporation (e.g. resulting in shareholder apathy), and information and coordination costs rose among shareholders (e.g. making it difficult to take collective action). ${ }^{55}$ Further, the interposition of Cede created a discrepancy between registered ownership (i.e. legal status as shareholder) and beneficial ownership (i.e. ownership of the share itself). ${ }^{56}$ To be sure, this incongruity did not formerly exist. In the direct holding system, a shareholder was a record holder entitled to notice and voting, and at the same time a beneficial owner having legal title.

A question begs itself, why have Delaware lawmakers not tailored DGCL to the nominee system as they did with UCC? Lawmakers understand the intricacies of the custodial ownership structure and its flaws, albeit refuse to alter their reliance on registered ownership in the voting context. ${ }^{57}$ This is because, lawmakers prioritize certainty attained from a company's reliance on a stockholder list (i.e. the registered owner is clearly specified and known to the company when identifying who is entitled to vote).$^{58}$ Further, Delaware courts have long affirmed that custodial arrangements between investors and securities intermediaries are primarily a matter of agency (not corporate law).$^{59}$ Issuers are isolated from custodial arrangements - to the extent that errors in the course of voting are borne by beneficial owners (and where appropriate custodians) but never by corporations. ${ }^{60}$ Despite the view taken by Delaware lawmakers, loose ends have serious practical consequences that perhaps should not be overlooked.

\section{Corporate Voting}

The solution to broken communication between issuers and investors was to create a proxy voting system, regulated by SEC Rules and DGCL provisions. However, this 'solution' ironically consolidated

\footnotetext{
${ }^{54}$ Concept Release on the U.S. Proxy Sys., Release No. 3052 (July 14, 2010).

${ }_{55}$ Panisi and others (n 50) 14. See also Reinier Kraakman and others, The Anatomy of Corporate Law: A Comparative and Functional Approach (3rd edn, Oxford University Press 2017) 30-31.

${ }^{56}$ Del. Code Ann. tit. 6, § 8-207 (West).

${ }^{57}$ Kahan and Rock (n 30) 1233.

${ }^{58}$ Geis (n 32) 9.

${ }^{59}$ Salt Dome Oil Corp. v. Schenck, 28 Del. Ch. 433, 41 A.2d 583 (1945).

60 By choosing to hold their securities through intermediaries, beneficial owners assume the risk that intermediaries might "act contrary to [their] interests." See Alabama By-Prod. Corp. v. Cede \& Co. on Behalf of Shearson Lehman Bros., 657 A.2d 254, 262 (Del. 1995). For instance, a mutual fund did not order nor approve certain ownership transfers undertaken by its intermediary bank. However, contractual agreements between beneficial owners and intermediaries typically permit the intermediary to re-title securities and in such cases Delaware law treats these transfers as voluntary - making the mutual fund accept such risk. See In re Appraisal of Dell Inc., No. CV 9322-VCL, 2015 WL 4313206, at *10 (Del. Ch. July 13, 2015), as revised (July 30, 2015). Notably, it is up to the private parties to sort out their misunderstandings - Delaware courts will not rectify the situation through equitable adjustments.
} 
discrepancies and proliferated problems. ${ }^{61}$ As such, this section examines the steps involved in voting (see figure 2), and their inefficiency.

\subsection{How Nominee Shares Are Voted}

a. Finding the beneficial owner: As the issuer fixes the shareholder meeting and record dates, it must formally announce them to DTC who would subsequently inform its members thereof. ${ }^{62}$ As of the record date, the issuer requests from DTC a securities position listing specifying each DTC member having holdings with the issuer. This allows the issuer (or typically its transfer agent) to verify the number of shares that each member is entitled to vote on its DTC proxy. DTC must respond to the issuer's query as of the record date. ${ }^{63}$

Subsequently, the issuer must send search cards to each DTC member. ${ }^{64}$ Search cards allow the issuer to determine if the intermediary holds issuer shares on behalf of beneficial owners, and if so, the number of proxy packages that need to be provided to beneficial owners. Notably, the amount of inquiries and information that must be passed increases with the multiplication of the types of intermediaries along the chain..$^{65}$

Upon receipt of search cards, brokers/ banks must supply requested information on the number of beneficial owners within a tight deadline. SEC Rules require brokers to respond within seven business days of receipt; ${ }^{66}$ banks must provide names and addresses of respondent banks ${ }^{67}$ within one business day and provide information on beneficial owners within seven business days. ${ }^{68}$ Expectedly, intermediaries in longer holding chains face a greater squeeze on time for transmitting and processing information, and thus, are more prone to error. ${ }^{69}$

${ }^{61}$ While our focus is on the US holding and voting systems, one must be mindful that problems experienced in domestic chains may further proliferate in cross-border chains. As more than one national law may apply to different parts of the chain. The holding and transfer of securities, and the exercise of investor rights becomes heavily cumbersome and legally uncertain. See Philipp PAECH, Cross-Border Issues of Securities Law: European Efforts to Support Securities Markets with a Coherent Legal Framework (Requested by the European Parliament's Committee on Economic and Monetary Affairs, Cm 464.416, 2011) 11. See also Morris and Glodstein (n 18) 33.

${ }^{62}$ Corporations listed on the NYSE are also required to notify NYSE of designated record and meeting dates. See 401.02 Notice to the Exchange, NYSE Listed Co. Manual s 401.02.

6317 C.F.R 140.17 Ad-8(b).

6417 C.F.R. $\S 240.14 a-13(a)(3)(i)$.

${ }^{65}$ Donald, 'The Rise and Effects of the Indirect Holding System' (n 4) 36.

6617 C.F.R. § $240.14 b-1(b)(1)$.

${ }^{67}$ SEC Rules describe respondent banks as exercising fiduciary power when holding securities on behalf of beneficial owners and depositing such securities for safekeeping with other banks, associations, or entities likewise exercising fiduciary powers. See 17 C.F.R § $240.14 \mathrm{c}-1$.

6817 C.F.R. § $240.14 b-2(b)(1)$.

${ }^{69}$ This can be seen, for example, in cross-border chains where there are domestic and foreign intermediaries passing information to shareholders across US borders. See OECD (2011), The Role of Institutional Investors in Promoting Good Corporate Governance, Corporate Governance, OECD Publishing; International Corporate Governance Network, 'Cross-Border Voting' (International Corporate Governance Network, July 2014) <www.icgn.org/policy/viewpoints/cross-border-voting> accessed 27 November 2019 
b. Distributing proxy materials: After having collected search cards, the issuer sends the securities intermediary (or its proxy service provider) copies of the proxy package (proxy cards, annual report, and proxy statement including a Notice of Internet Availability of Proxy Materials) which it must forward to beneficial owners within five business days from receipt date. ${ }^{70}$ Typically, the distribution function is delegated to and carried by Broadridge - a proxy service provider.

c. Voting: As the record holder Cede retains the formal right to vote, how are votes actually cast by beneficial owners? DTC executes a single (or omnibus) proxy granting each custodian member the right to cast Cede's vote in proportion to their total allocation. ${ }^{71}$

For instance, if JP Morgan Chase reports that its clients hold a 25\% stake then DTC will issue a proxy permitting the bank to vote a quarter of issuer shares. ${ }^{72}$ JP Morgan Chase will then execute another omnibus proxy in favor of respondent banks (further fragmenting proxy rights according to their holding stake); these respondent banks will then execute an omnibus proxy in favor of their respondents; ${ }^{73}$ and the process recurs until the last security intermediary. ${ }^{74}$ This allows issuers to efficiently follow the chain of intermediaries beginning with large international banks belonging to DTC all the way to regional banks with which beneficial owners have a direct account. ${ }^{75}$

The last security intermediary proceeds by disseminating proxies or (typically) soliciting voting instructions from beneficial owners. ${ }^{76}$ Beneficial owners will indicate their voting instructions on a voting instruction forms ("VIF") and remit it to the securities intermediary (or its proxy service provider) via mail, telephone, or the internet. ${ }^{77}$ The securities intermediary then aggregates instructions and casts votes with the issuer - in accordance to beneficial owners' wishes. ${ }^{78}$

d. Vote tabulation: DGCL requires issuers to appoint tabulators to collect and count proxy votes, and votes conveyed by shareholders attending the meeting. ${ }^{79}$ Tabulators will verify the number of votes submitted by securities intermediaries by comparing them against DTC's securities position listing. However, their task is purely formalistic and ministerial (e.g. ascertaining if proxies meet formal criteria). ${ }^{80}$

If a disputed issue arises, the tabulator simply reports it to the corporation and then the voting outcome may be challenged before a court (if any). Even materials which the tabular is permitted to rely on for

7017 C.F.R. $\S 240.14 b-1(b)(2)$ (for brokers) and § 240.14b-2(b)(3) (for banks).

${ }^{71}$ It is common practice to execute a single proxy instead of separate proxies for each DTC member. However, it is neither automatic nor mandatory. See Kurz v. Holbrook, 989 A.2d 140 (Del. Ch.), judgment entered, (Del. Ch. 2010), and aff'd in part, rev'd in part sub nom. Crown EMAK Partners, LLC v. Kurz, 992 A.2d 377 (Del. 2010)

${ }^{72}$ Geis (n 32) 10.

7317 C.F.R. § 240.14b-2(b)(2)(i).

${ }^{74}$ Kahan and Rock (n 30) 1247.

${ }^{75}$ Donald, 'The Rise and Effects of the Indirect Holding System' (n 4) 27.

${ }^{76} 17$ C.F.R. $\S 240.14 b-2(3)(i)$ and (ii).

${ }^{77}$ Concept Release on the U.S. Proxy Sys (n 54) ch II, pt b, 19-20.

7817 C.F.R. § 240.14a-4(e).

${ }^{79}$ Del. Code Ann. tit. 8, § 231(a) (West).

${ }^{80}$ Emerald Partners v. Berlin, 726 A.2d 1215 (Del. 1999). 
verifying votes are restricted - save for cases of over-voting. ${ }^{81}$ In such cases, when a security intermediary submits more votes than it is entitled to cast by the registered owner, then the tabulator may count votes on a first-in basis or may exclude votes as necessary. ${ }^{82}$ By granting tabulators some leeway in resolving over-votes corporate law recognizes that custodial ownership increases the likelihood of errors.

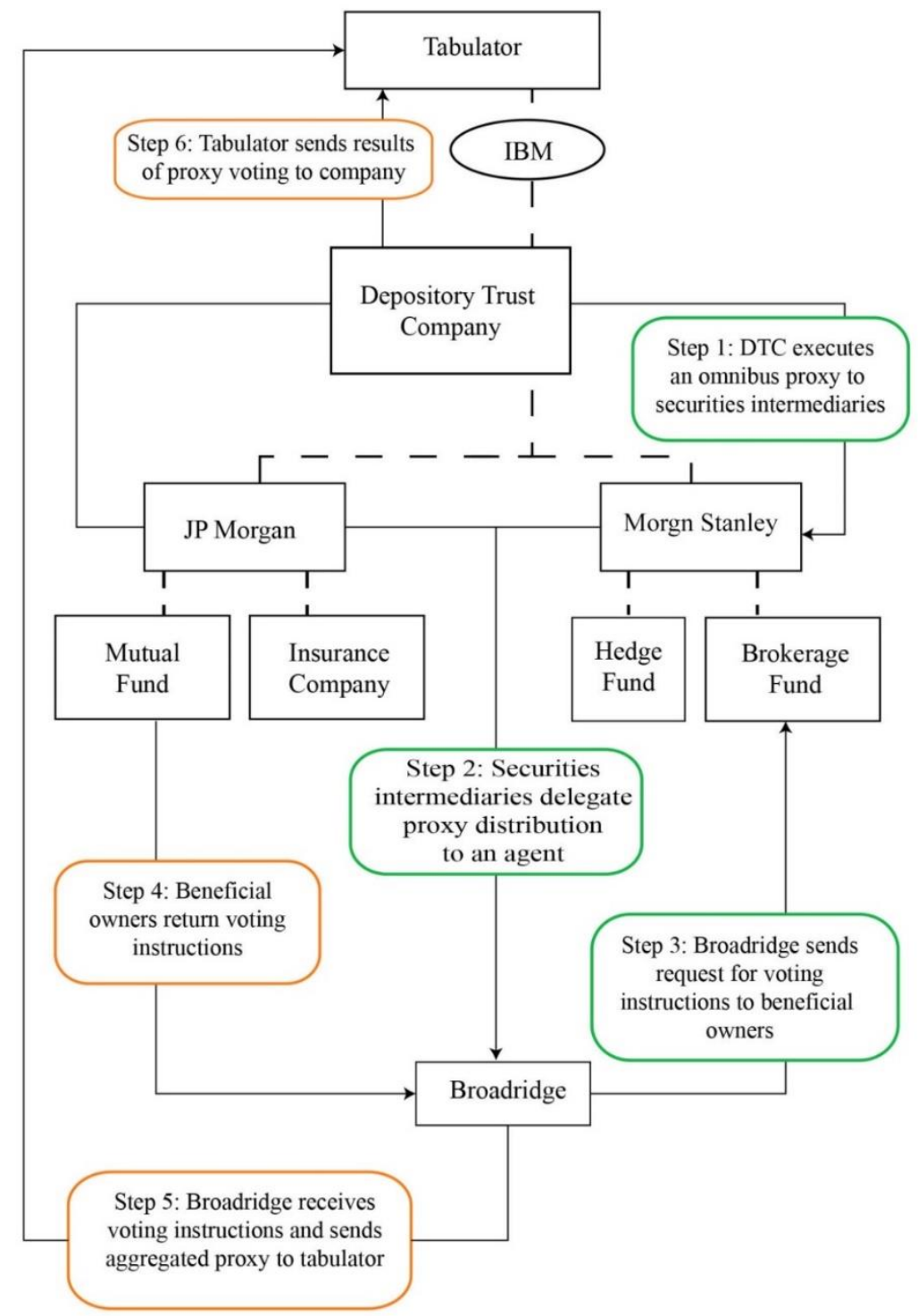

Figure 2: How Nominee Shares are voted

${ }^{81}$ Del. Code Ann. tit. 8, § 231(d) (West).

${ }^{82}$ Concept Release on the U.S. Proxy Sys (n 54) ch III, pt A, 26. 


\subsection{Inefficiencies of Proxy Voting}

After proxy rules were tailored to fit the nominee system, the communication process turned into a complex game of 'pin the proxy on the beneficiary'.$^{83}$ In this game, all participants play blindfolded and can only observe their next proximate player (e.g. a last-tier respondent bank will not know if information by a DTC participant was altered when passed along other respondent banks).$^{84}$ Ironically, the high degree of anonymity that has come to characterize the voting system is akin to that of a system of bearer shares (where an issuer has no record of its shareholders). Of course, this is inconsistent with DGCL which is premised on registered ownership (i.e. a corporation can look to its stockholder list to find those is entitled to vote and communicate with them) ${ }^{85}$ Anonymity leads to operational risk, particularly failure to exercise shareholder rights, undermines the efficacy and efficiency of corporate governance. ${ }^{86}$

Another contradiction featured in this game is that a beneficial owner's right to vote under SEC Rules is at odds with DGCL which only entitles registered owners to notice of shareholder meeting and voting ${ }^{87} \mathrm{~A}$ final limitation to this game is that time set between the record date and the shareholders meeting (tensixty days) ${ }^{88}$ may not suffice for completing all voting steps whilst still allowing beneficial owners to make informed decisions in due time.

The SEC is aware that complexity stems, in part, from the fact that issuers do not know who their shareholders are.$^{89}$ Thus, in attempt to create direct communication ${ }^{90}$ SEC Rules grant issuers the right to request from brokers/ banks a list disclosing the identity of beneficial owners who do not object to their identities being disclosed ("NOBO"). ${ }^{11}$ At the outset, this measure seems to remove many communication problems. However, the catch is that NOBO lists may be used by issuers only for distributing the annual report or for voluntary communications with beneficial owners. Proxy materials must still be distributed indirectly through extensive layers of intermediaries. ${ }^{92}$ Notwithstanding, $60 \%$ of traded shares are held by objecting beneficial owners (opposite to NOBO) which means that issuers cannot communicate 'directly' with a large portion of shareholders. ${ }^{93}$

A careful thought about the structures of ownership and voting leads us to reason that communication will remain distorted by the interposition of intermediaries, so long that DGCL relies on registered shares in the voting context and/or shares are registered in Cede's name. For instance, if SEC Rules permit distribution of proxy cards immediately to beneficial owners (without having to pass intermediaries), these beneficial owners (by definition) are not entitled to vote under corporate law (as opposed to

${ }^{83}$ Donald, 'Heart of Darkness' (n 7) 67.

${ }^{84}$ Ibid.

86 Oxford Economic Research Associates, 'Corporate Action Processing: What are the Risks?' (Sponsored by Depository and Trust Clearing Corporation, Oxford Economic Research Associates May 2004) ch 3.0 , 12 <www.oxera.com/wp-content/uploads/2018/03/Corporate-action-processing.pdf>.

${ }^{87}$ Donald, 'Heart of Darkness' (n 7) 67.

${ }^{88}$ Del. Code Ann. tit. 8, § 213 (West).

${ }^{89}$ Kahan and Rock (n 30) 1244.

${ }^{90}$ Facilitating S'holder Commc'ns Provisions, Release No. 13408 (July 28, 1983).

${ }^{91} 17$ C.F.R. § 240.14b-1(b)(3)(i) in connection with § 240.14a-13(b)-(c).

92 Donald, 'The Rise and Effects of the Indirect Holding System' (n 4) 26.

${ }^{93}$ Concept Release on the U.S. Proxy Sys (n 54) ch IV, pt A, 67. 
registered owners). Effectively, beneficial owners will always depend on intermediaries for granting them voting rights, and thereafter for executing the vote on their behalf.

\section{Pathologies of Shareholder Voting}

As anticipated, complexities of the ownership structure together with intricacies of the voting process yields an infrastructure that is far more troubling than anticipated by Delaware corporate law. The following section discusses some voting pathologies that foul the accuracy, transparency, and costefficiency of shareholder voting.

\subsection{Pathologies of Complexity}

This pathology refers to the complexity of the nominee system, coupled with the circuitous system of distributing materials, soliciting proxies, and collecting votes. ${ }^{94}$ In the midst of this commotion, beneficial owners cannot confirm that their shares have been accurately voted - according to their instructions. ${ }^{95}$ This is a nightmare, especially for institutional investors who need to confirm their votes on matters that are meaningful and consequential such as in appraisal claims.

However, inability to confirm the accuracy of votes stems from a bigger problem: inability to confirm how shares have been voted. This is caused partly, due to the fact that no participant (e.g. transfer agents, security intermediaries, proxy service providers, etc.) possesses all information needed to verify how a beneficial owner's particular shares have been voted. ${ }^{96}$ Some participants contend that transfer agents, proxy service providers, and vote tabulators possess such information but are unwilling to share it. If true, there is no piece of legislation that currently compels them to share information that would allow vote confirmation. ${ }^{97}$

Consider this pathology in light of appraisal claims. Appraisal law permits investors to sue for the fair market value of their shares, if they abstain or vote against a merger or related fundamental transaction..$^{98}$ If beneficial owners continuously hold shares from the announcement date until the shareholder vote, then perfecting an appraisal claim will be relatively straightforward: beneficial owners can rely on VIFs to prove that their particular shares were voted appropriately. However, when investors buy a block of stock after the record date it becomes impossible to demonstrate this. ${ }^{99}$ Why? Assuming no participant possesses relevant information, it is impossible to trace how beneficial owners' particular shares were voted by the record owner in a world of fungible bulk.

This idea is illustrated by a case where Transkaryotic Therapies ("Transkaryotic") entered into a merger transaction with Shire Pharmaceuticals for $\$ 37 /$ share. ${ }^{100}$ A group of twelve investors holding nearly eleven million shares disliked the price, and filed for an appraisal remedy. Eight million of their total

\footnotetext{
${ }^{94}$ Kahan and Rock (n 30) 1249.

95 J Travis Laster (n 51) 8.

${ }^{96}$ Concept Release on the U.S. Proxy Sys (n 54) ch III, pt B, 39.

${ }^{97}$ Ibid.

${ }^{98}$ Del. Code Ann. tit. 8, § 262(a) (West).

${ }^{99}$ Geis (n 32) 18.

${ }^{100}$ In re Appraisal of Transkaryotic Therapies, Inc., No. CIV.A. 1554-CC, 2007 WL 1378345 (Del. Ch. May 2, 2007).
} 
shares were bought after the record date, but before shareholders meeting where votes are tallied (i.e. the deadline for filling an appraisal claim). ${ }^{101}$

The passage of the record date meant that these investors were not entitled to vote the eight million shares - but could they nonetheless be eligible to compensation on the said shares? DGCL stipulates that only the record owner may claim and perfect appraisal rights. ${ }^{102}$ As such, only Cede's actions could determine standing of the twelve investors to appraisal rights. ${ }^{103}$

Against this backdrop, the court considered how Cede voted its position: 12.9 million shares voted yes against 16.9 million shares voted no and abstained. ${ }^{104}$ The next step was to determine whether the plaintiffs' shares fell within the former or latter group - if they are attributable to the latter group then plaintiffs are eligible for an appraisal remedy.

Answering this question requires matching ownership with votes cast on a share-by-share basis, or as at least making such match on the record date without further ownership changes for the pertinent shares. Of course, the reality of equity markets dictates that this is not plausible - unless there is some forensic evidence that proves how shares were voted. In this case (as in other typical cases) the court did not have evidence. $^{105}$

Surprisingly, the court concluded that beneficial owners who purchase shares after the record date but before the merger vote, need not prove that previous beneficial owners had abstained/ dissented. As long as the record owner held enough shares (not voted in favor of the merger) to cover the beneficial owners' shares, the record owner could assert appraisal rights on the beneficial owners' eight million shares. ${ }^{106}$

The court's approach is problematic. It permits an indeterminate inquiry into the genealogy of shares, without affirming that shares bought post record date are in actuality those which did not vote in favor of a merger. Of course, this casts doubt about the accuracy and integrity of votes cast. ${ }^{107}$ Particularly in meetings where there is a matter in controversy, the lack of transparency may impair confidence in the proxy system. This ruling also undesirably gives room for appraisal arbitrage, ${ }^{108}$ a situation where latecomers take advantage of fault lines between statutory theory and reality to routinely object to mergers by insisting that their shares qualify as part of Cede's dissenting/ abstaining votes. ${ }^{109}$

\subsection{Pathologies of Ownership}

The second pathology is the imbalance caused by misalignment of property rights under DGCL (i.e. beneficial owners directly own specific shares) and those under UCC (i.e. beneficial owners own a pro

\footnotetext{
${ }^{101}$ Ibid [1] (Chandler, J).

102 Del. Code Ann. tit. 8, § 262(a) and § 262(h) (West).

103 Transkaryotic Therapies [3] (Chandler, J)

104 Ibid [1] (Chandler, J).

105 Geis (n 32) 21.

106 Transkaryotic Therapies [2], [5] (Chandler, J)

${ }^{107}$ J Travis Laster (n 51) 14.

108 Transkaryotic Therapies [5] (Chandler, J).

${ }^{109}$ Geis (n 32) 21.
} 
rata interest in a fungible bulk). ${ }^{110}$ The effect of this imbalance becomes particularly noticeable as the financial market adopts innovative practices such as margin lending and short selling.

Margin lending describes an arrangement, where individual investors borrow money from their brokers to finance share purchases in exchange for pledging a portion of their existing stock portfolio. ${ }^{111} \mathrm{~A}$ standard margin agreement between brokers and customers, grants brokers the right to lend out collateralized securities in order to fund the loan. ${ }^{112}$ Consequently, brokers enter into stock loan agreements with institutional investors (e.g. hedge funds) or other brokers to lend the said shares against a financing fee.

Borrowers typically borrow these shares to carry out a short sale, given that naked short selling is illegal. ${ }^{113}$ Further, a standard stock loan agreement transfers legal title from the lending customer or investor to the borrower. In turn, the borrower promises to sell back equivalent but different shares in the future, inter alia. ${ }^{114}$ If shares are lent out before the record date, the lending investor is not a shareholder as of the record date - even if shares are returned prior to the shareholders meeting. Effectively, the lender loses the right to vote (although retains economic rights attached to the loaned securities), whereas the borrower obtains such right. ${ }^{115}$ Of course, this de facto transfer of beneficial interest and voting right is replicated when the borrower engages in a short sale. ${ }^{116}$

Brokers will not match a particular number of shares as having been borrowed from a given account (since shares are held in fungible bulk). ${ }^{117}$ That is brokers, will not know which investors have lost their right to vote, and will in turn, solicit and receive instructions for more shares than their entitled to vote. ${ }^{118}$ Take a hypothetical situation where, Morgan Stanley has 1 million shares of Amazon in its DTC account, while Fidelity Investments has 500,000 shares. ${ }^{119}$ A hedge fund customer borrows 100,000 shares from Morgan Stanley and short sells them to a customer of Fidelity. DTC records will be updated such that Fidelity has 600,000 shares in its DTC account and Morgan Stanley has 900,000 shares. To enable voting of these shares, DTC will execute an omnibus proxy transferring the right to vote 900,000 shares to Morgan Stanley. Then, Morgan Stanley will give its proxy service provider (Broadridge) a list of its customers' holdings for 1 million shares - given that it has not adjusted its books to reflect the securities loan. If Broadridge follows that customer list to distribute VIFs, the outcome will be overvoting. ${ }^{120}$

\footnotetext{
${ }^{110}$ Kahan and Rock (n 30) 1255.

${ }^{111}$ Nord (n 33) 718.

112 Ibid.

11317 C.F.R. § 242.203.

${ }^{114}$ Kahan and Rock (n 30) 1255.

${ }^{115}$ Henry TC Hu and Bernard Black, 'Empty Voting and Hidden (Morphable) Ownership: Taxonomy, Implications, and Reforms' [2006] 61 The Business Lawyer 1011, 1015.

116 Kahan and Rock (n 30) 1257.

${ }^{117}$ Assigning particular shares of a security to a particular investor is also impossible due to the practice of netting. See Concept Release on the U.S. Proxy Sys (n 54) ch III, pt A, 28-29.

118 Ibid.

${ }^{119}$ Kahan and Rock (n 30) 1258-1259.

${ }^{120}$ Ibid.
} 
If Broadridge and Morgan Stanley submit a higher number of votes than entitled, that may result in the tabulator invalidating all votes pertaining to Amazon's stock. As such, Morgan Stanley may attempt to reconcile votes in different, yet rudimentary, ways: (i) assign the total number of shares they are eligible to vote on a pro rata basis to their customers before or after VIFs are sent; or (ii) simply downsize the total number of votes cast. ${ }^{121}$ The latter reconciliation method is particularly problematic because brokers must almost arbitrarily decide whose vote counts. ${ }^{122}$ Overall, uncertainty as to who owns a specific share casts doubt about the accuracy and integrity of shareholder voting - especially in view of ineffective reconciliation methods and the lack of industry consensus thereof. ${ }^{123}$

\subsection{Pathologies of Misalignment}

Delaware corporate governance presumes that shareholders as owners of economic return on shares, are best suited to collectively govern a corporation because they bear the entrepreneurial risk inherent thereto. ${ }^{124}$ It follows that, shareholder democracy is preserved by distributing votes based on number of shares owned (not by number of owners). ${ }^{125}$ However, the assumption that one share equates to one vote is increasingly challenged in today's equity markets by the practice of empty voting (i.e. the third pathology).

Empty voting refers to the holding of more votes than shares, hence, votes are 'emptied' from their economic interest. ${ }^{126}$ This practice emerges from the mismatch between theoretical statuary construct (assuming votes are coupled with beneficial ownership including economic interest) and the actuality of trade markets (where it is procedurally impossible to ascertain beneficial ownership to a specific share due to fungibility). ${ }^{127}$ Notably, event-driven hedge funds and activist investors have exploited this mismatch to advance their interests, often at the expense of shareholder democracy theory. ${ }^{128}$

A classic example of empty voting is the sale of shares after the record date but prior to the shareholders meeting date. The upshot, is that sellers maintain voting rights at the meeting whilst economic ownership is held by buyers. To the extent that this is done intentionally, shareholders may well vote them in a manner that reduces the value of the company. ${ }^{129}$ Even if empty voting is done unintentionally, the election outcome may be systematically inferior due to shareholder apathy. ${ }^{130}$ As shareholders have already sold their position in the corporation, they have no or little reason to care about election results.

Empty voting in the aforementioned manner (whether intentionally or not) will most likely weaken shareholder democracy (i.e. dilute shareholders' voting rights and control over corporate decisions). This weakening effect magnifies as more and more shares are traded in the interval between the record and

\footnotetext{
${ }^{121}$ Concept Release on the U.S. Proxy Sys (n 54) ch III, pt b, 31-32.

${ }^{122}$ Kahan and Rock (n 30) 1260.

${ }^{123} \mathrm{Hu}$ and Black (n 115) 1064.

${ }^{124}$ Panisi and others (n 50) 3.

${ }^{125} \mathrm{Hu}$ and Black (n 115) 1013-1014.

126 Ibid.

${ }^{127}$ Panisi and others (n 50) 28.

${ }^{128} \mathrm{Hu}$ and Black (n 115) 1011.

${ }^{129}$ Panisi and others (n 50) 17.

${ }^{130}$ Kahan and Rock (n 30) 1267.
} 
meeting dates. ${ }^{131}$ In turn, judiciary bodies have attempted to do some damage control by granting succeeding beneficial owners the right to require predecessor beneficial owners to execute a proxy transferring the right to vote back to them. ${ }^{132}$ However, where physical shares no longer change hands it is impossible to match individual sellers with buyers.

The repercussions of empty voting are most consequential to shareholders where controversy exists about the outcome of a shareholders meeting. ${ }^{133}$ Consider a real life situation where, an event-driven hedge fund used hedging and other modern financial innovations to object to an acquirer's plan to buy a target. This is a paradigma on how empty voting can empower one group of shareholders (event-driven hedge funds) against another disempowered group (acquirer's shareholders). ${ }^{134}$

Subject to shareholders' approval, Mylan Laboratories Inc. ("Mylan") wished to acquire King Pharmaceuticals Inc. ("King”) in exchange for Mylan shares. ${ }^{135}$ Hedge fund Perry Corp. ("Perry") had a significant ownership stake in King, and stood to benefit from a 61\% premium offered by Mylan. Conversely, Mylan shareholders publicly opposed the merger for being too costly - resulting in a fall of Mylan share price. ${ }^{136}$

To secure its profits, Perry needed to influence Mylan's shareholder decision. It bought $9.9 \%$ of Mylan shares, becoming the largest shareholder, but fully hedged the market risk associated with the Mylan shares through equity swaps. ${ }^{137}$ The result: Perry had $9.9 \%$ voting ownership of Mylan but zero economic ownership. ${ }^{138}$ That guaranteed Perry the completion of the merger through a majority vote, with indifference to whether the transaction was value creating or diminishing for Mylan shareholders. Put differently, if Mylan was overpaying for King then Perry would have no exposure to the declining economic returns. ${ }^{139}$

\subsection{Financial Costs}

The fourth pathology demonstrates how stockholding and voting systems are expensive. It is estimated that, $\$ 100$ billion is paid annually for post-trade services ${ }^{140}$ and $\$ 200$ billion for communication services. ${ }^{141}$ Inevitably, these costs are passed on from issuers to investors. ${ }^{142}$

\footnotetext{
131 Geis (n 32) 24.

${ }^{132}$ Latham \& Watkins, ‘M\&A: Deal Commentary’ (Latham \& Watkins April 2007) pt Record Date vs. Meeting Date <www.lw.com/upload/pubContent/_pdf/pub1878_1.Commentary.Empty.Voting.pdf> accessed 29 November 2019. 
While issuers have complained to SEC about unreasonableness of these fee, they seem to forget that single firms have come to enjoy dominance in clearance, settlement, and proxy processes. For instance, Broadridge controls over $98 \%$ of the US market for proxy processing services. ${ }^{143}$ While SEC has been cautious in making regulatory changes, surely where natural monopolies exist they should be regulated as utilities in order to protect interests of issuers and investors at stake. ${ }^{144}$

Expectedly, intermediaries have no interest in moving to a system of direct communication and/ or voting because that threatens their raison d'être. Brokers/ banks have interests in preserving income derived from forwarding proxy materials, and preserving stock loan revenues which would be at risk if clients had greater transparency about loan practices. ${ }^{145}$ The threat is strongest for Broadridge, whose core business is selling information and communication services to issuers. ${ }^{146}$

\section{A Potential Solution: Blockchain}

The preceding section highlighted how the US proxy voting system is rife with inefficiency, inaccuracy, and opaqueness - as illustrated by the voting pathologies. Primarily, voting pathologies arose due to Congress's decision to transition into the IHS pursuant to which most shares are held in Cede's name as a fungible bulk that is not traceable to any beneficial owner.

If the pathologies associated with voting are largely a function of the IHS, then the threshold question is whether an alternative to this plumbing system exists. In theory, the answer is yes. A new clearing and settlement system on blockchain may facilitate the voting process and potentially mitigate/ eliminate pathologies. However, adoption remains farfetched unless federal and/ or state law is amended to prescribe for blockchain's novel processes.

\section{Blockchain Trends}

The financial market has been buzzing with talk about blockchain's potential to automate or even replace functions traditionally played by intermediaries (e.g. CSDs, brokers/ banks, etc.) in clearing and settlement processes (“CSPs"). Incumbents are rushing to partner with FinTech startups to streamline some functions of CSPs, whilst more radical alternatives to existing arrangements are emerging by other startups. ${ }^{147}$ For instance, DTCC partnered with IBM to settle credit derivatives on blockchain. ${ }^{148}$ In

141 Kevin Kearney, 'Proxy.gov: A Proposal to Modernize Shareholder Lists and Simplify Shareholder Communications' (2015) 37 Hastings Communications and Entertainment Law Journal 391, 397.

142 J Travis Laster (n 51) 15.

143 Broadridge, 'Portfolio Securities Voting' (Broadridge Financial Solutions) < www.broadridge.com/financialservices/asset-management/institutional-investors/enhance-and-simplify-portfolio-management/portfolio-

securities-voting> accessed 29 November 2019.

${ }^{144}$ CII Letter 31 Jan 2019 (n 3) 9.

${ }^{145}$ Council of Institutional Investors, The OBO/NOBO Distinction in Beneficial Ownership: Implications for Shareowner Communications and Voting (Cm S7-14-10, February 2010) 1.

146 Ibid.

147 Michael Mainelli and Alistair Milne, 'The Impact and Potential of Blockchain on the Securities Transaction Lifecycle' (2016) SWIFT Institute 48 <www.swiftinstitute.org/wp-content/uploads/2016/05/The-Impact-andPotential-of-Blockchain-on-the-Securities-Transaction-Lifecycle Mainelli-and-Milne-FINAL-1.pdf> accessed 29 November 2019. 
another instance, a startup called SETL designed a public blockchain for brokers to settle crypto-currency payments in real-time. ${ }^{149}$

While these initiatives do not impact clearing and settlement of securities of publicly listed companies, evangelists are hopeful it will. ${ }^{150}$ They contend that migrating existing CSPs onto blockchain (e.g. if DTC adopts the technology for public equity) will merely generate cost-savings and increase operational efficiency (e.g. by reducing settlement time) but will fail to solve voting pathologies. ${ }^{151}$ As such, they rally for a radical overhaul of US CSPs.

\section{What is Blockchain}

At the most basic level, blockchain is a type of distributed ledger that stores ownership information pertaining to all participants in the system. ${ }^{152}$ The information may be accessible by all participants running the same protocol (i.e. rules governing the exchange of instructions between users). ${ }^{153}$ There are two features underpinning the concept of blockchain: distributed ledgers and cryptography.

\subsection{Distributed Ledgers}

Today DTC is the central authority that verifies holdings and settles transactions, using double-entry bookkeeping, on behalf of its participating banks/ brokers. ${ }^{154}$ Likewise, banks/ brokers are trusted by investors to privately maintain ownership records and to transfer assets on their behalf. Each intermediary, though interacting with another, will reflect the relevant transaction on its own single copy of the ledger. ${ }^{155}$ As such, traditional bookkeeping ledgers are stored and maintained privately by each relevant intermediary.

148 Michael del Castillo, '\$11 Trillion Bet: DTCC to Process Derivatives With Blockchain Tech' (COINDESK, 21 December 2017 <https://www.coindesk.com/11-trillion-bet-dtcc-clear-derivatives-blockchain-tech> accessed 29 November 2019.

${ }_{149}$ Jemima Kelly, 'Computershare teams up with start-up SETL on blockchain project' (Reuters, 28 April 2016) $<$ www.reuters.com/article/us-securities-blockchain-computershare/computershare-teams-up-with-start-up-setlon-blockchain-project-idUSKCNOXP1NL> accessed 29 November 2019.

${ }^{150}$ Matthew Toole and others, 'The First Block in the Chain: Proposed Amendments to the DGCL Pave the Way for Distributed Ledgers and Beyond' (Harvard Law School Forum on Corporate Governance and Financial Regulation, 2017) <https://corpgov.law.harvard.edu/2017/03/16/the-first-block-in-the-chain-proposed-amendments-to-thedgcl-pave-the-way-for-distributed-ledgers-and-beyond/> accessed 29 November 2019.

${ }^{151}$ US Securities and Exchange Commission, 'Roundtable on the Proxy Process' (Chairman Jay Clayton cautions the participants about potential changes to the existing securities trading and clearing system, Washington DC, November 2018) <www.sec.gov/spotlight/proxyprocess/proxyvotingbrief.htm> accessed 27 November 2019.

${ }^{152}$ David Mills and others, 'Distributed Ledger Technology in Payments, Clearing, and Settlement' (2016) Board of Governors of the Federal Reserve System Working Paper 2881204, 12 <file://C:/Users/User/Downloads/SSRNid2881204.pdf> accessed 29 November 2019.

153 Wonnie Song, 'Bullish on Blockchain: Examining Delaware's Approach to Distributed Ledger Technology in Corporate Governance Law and Beyond’ (2017) 8 Harvard Business Law Review 9, 10.

${ }^{154}$ Toole and others (n 150) para 3.

${ }^{155}$ Mills and others (n 152) 6-7. 
Alternatively, blockchain's ledger is shared or 'distributed' across computer systems (or nodes) of all participants. ${ }^{156}$ Settlement involves broadcasting proposed transactions to nodes that maintain an identical copy of the ledger (containing historical and pending transactions). If all nodes agree to the updated version of the ledger, via a consensus protocol, then the transaction is permanently recorded. ${ }^{157}$

\subsection{Cryptography}

Blockchain uses cryptography for multiple reasons, including data encryption and identity verification. ${ }^{158}$ For example, an asset transfer requires a public encryption key for recording ownership, and a private encryption key for confirming that the owner of the asset has truly initiated the transfer. ${ }^{159} \mathrm{~A}$ public key is analogous to an email address for other participants to interact with, while a private key is akin to login credentials that permit senders to effect transactions from their addresses. ${ }^{160}$

An asset transfer made by a given sending address must be signed with the appropriate private key otherwise the transaction will not queue for processing. ${ }^{161}$ Once queued, other participants in the network may act as validators by decrypting the ledger entry with a mathematical algorithm and the asset owner's publicly available public key. ${ }^{162}$ This process is termed 'consensus'.

Once validated, the transaction is time-stamped and grouped with other validated transactions in a chronological order to create a new block of transactional data. The new block is added to preexisting blocks in the ledger, thereby, formulating a 'blockchain'. Finally, the updated ledger is distributed among participants and a new cycle begins anew. ${ }^{163}$

To remain technically correct, the description given herein pertains to a public permissionless blockchain such as the one adopted by bitcoin. ${ }^{164}$ In a nutshell, a public permissionless blockchain is a ledger that is viewable and modifiable by any user if they fulfill the consensus protocol. Alternative forms exist, such as a private permissioned blockchain whereby the ledger is viewable and modifiable only by preauthorized participants. ${ }^{165}$ The particularities of private permissioned blockchain are examined in the next subsection.

\footnotetext{
${ }^{156}$ Geis (n 32) 29-30

157 Toole and others (n 150) para 3.

${ }^{158}$ Mills and others (n 152) 13.

159 Ibid 12.

${ }^{160}$ Nord (n 33) 722.

${ }^{161}$ Park Bramhall, 'Blockchain Isn't Always the Solution (or Why Tokenizing Equity Securities is not the Answer to the Proxy Voting Problem)' (2019) Working Paper 3393774, 7 < file:///C:/Users/User/Downloads/SSRNid3393774.pdf> accessed 29 November 2019.

162 Mills and others (n 152) 12-13.

${ }^{163}$ Reade Ryan and Mayme Donohue, 'Securities on Blockchain' (2017) 73 Business Lawyer 85, 89.

164 Geis (n 32) 29.

165 Alexandros L Seretakis, ‘Blockchain Securities Markets and Central Banking' (2017) Trinity College Dublin Working Paper 3007402, pt 1, para 4-5 <file://C:/Users/User/Downloads/SSRN-id3007402.pdf> accessed 29 November 2019.
} 


\section{Overhaul of Existing CSPs}

\subsection{Envisioning CSPs on Blockchain}

In the context of CSPs, one can imagine a consortium of intermediaries creating a private permissioned blockchain for the corporation and its shareholders (see figure 3). ${ }^{166}$ Because it is permissioned, the organization representing consortium members (e.g. brokers/ banks) acts as a gatekeeper. ${ }^{167}$ It is the only participant authorized to grant access to the system, and to enter and update its contents. ${ }^{168}$ The right to publish changes to the distributed ledger may not require solving a mathematical algorithm as in a public permissionless blockchain. ${ }^{169}$ Instead, the gatekeeper is preauthorized to simply add the new block whenever sufficient transactions are queued to justify the next link in the chain. Further, the gatekeeper is the only participant empowered to operate the platform, and make decisions regarding rules and technology upgrades.

A private blockchain entitles certain participants to operate a node on the blockchain and view the ledger's contents. ${ }^{170}$ Thus, in our proposed model there are multiple copies of the ledger that can be viewed only by the issuer and its transfer agent; shareholders and their proxy advisors; and regulators. ${ }^{171}$ However, neither the corporation nor other shareholders are able to view the identities, holdings, and voting positions of other individual shareholders. ${ }^{172}$ For obvious reasons, maintaining a public blockchain where sensitive data is transparent to all participants is undesirable. ${ }^{173}$ Moreover, the private permissioned blockchain accommodates CSPs by transferring securities that are digitally represented on blockchain ${ }^{174}$ while transferring funds off the chain. ${ }^{175}$

More precisely, how would the private permissioned blockchain achieve CSPs? A share of stock continues to trade electronically through brokers/ banks and exchanges, but the details of each trade are processed and executed on blockchain. An investor wanting to buy/ sell shares would contact a permissioned broker/ bank (acting as gatekeeper) to execute the trade. ${ }^{176}$ The gatekeeper will grant the investor access to the system, and hence, the ability to own tokens if she satisfies disclosure obligations and Know-Your-

166 The private permissioned model suggested herein is primarily inspired by the proposal of the Council of Institutional Investors. Notwithstanding, other blockchain forms have been proposed to improve CSPs and voting processes. See CII Letter 31 Jan 2019 (n 3) 1; CII Letter 8 Nov 2018 (n 3) 4.

${ }^{167}$ CII Letter 8 Nov 2018 (n 3) 5; Geis (n 32) 37.

${ }^{168}$ Seretakis (n 165) pt 1, para 4-5.

${ }^{169}$ Geis (n 32) 37-38.

${ }^{170}$ CII Letter 8 Nov 2018 (n 3) 5.

171 The distributed ledger would be fully transparent to SEC. It would be allowed to view information for oversight and enforcement purposes, and as appropriate collect information about certain transactions that trigger regulatory action. See CII Letter 31 Jan 2019 (n 3) 7.

172 This is possible by encrypting privacy relevant information on the ledger. See Mills and others (n 152) 13.

173 David Yermack, 'Corporate Governance and Blockchains' (2017) Oxford University Press Review of Finance 7, 17.

${ }^{174}$ As opposed to having securities natively issued on blockchain, tokens are coded data representing a security on the ledger. See Mills and others (n 152) 25.

${ }^{175}$ Several arrangements are possible to ensure that investors' funds are available to stand behind trades in a manner that is consistent with existing arrangements between brokers/ banks and clients. See Geis (n 32) 37.

176 Ibid 36-37. 
Customer/Anti-Money Laundering checks done off the chain. ${ }^{177}$ Once satisfied, the gatekeeper records proof of authentication on blockchain and issues a private/ public key for the shareholder. Recall, that a gatekeeper need not solve an algorithmic puzzle to authenticate the ledger entry as in a public permissionless blockchain.

Next the broker locates a counterparty and agrees with it on the terms of the trade, as in existing arrangements. This is followed by clearing, which significantly differs from existing arrangements in that no central counterparty ("CCP") interposes itself as buyer to every selling broker and seller to every buying broker to guarantee a trade is eventually settled even if one of the parties default or windup. ${ }^{178}$ This obviates the need for National Securities Clearing Corporation ("NSCC") that novates securities transactions. Without NSCC's guarantee, settlement and counterparty risks may increase. ${ }^{179}$ Arguably, risk is mitigated because a smart contract settles a trade only if both parties have met their obligations. ${ }^{180}$ By way of background, a smart contract is an inputted data instruction (transfer of securities) that is predefined at inception of a relationship, and executed upon the realization of an event (seller has ownership of tokens, and buyer has access to sufficient funds). ${ }^{181}$ As such, a smart contract ensures that only quality validated data enters the ledger - simplifying processing and minimizing error corrections compared to existing CSPs. ${ }^{182}$

Further, blockchain records each individual transaction on the ledger in real time. This forgoes an imperative advantage created by fungible bulk - not having to record adjustments for every trade. By way of explanation, consider a trader that makes 10 buys and 9 sells of Amazon stock in one day. ${ }^{183}$ Under existing CSPs, a broker need not worry about clearing all of these positions - it can simply offset its client's buy and sell orders at the end of the day (i.e. net) such that it only records one share of Amazon stock for that trader. Similarly, NSCC consolidates securities positions of brokers to reduce the number of securities that must be delivered and the amounts paid from and to brokers' DTC account. ${ }^{184}$ Alternatively, blockchain eschews the function of netting traditionally performed by brokers ${ }^{185}$ and NSCC since individual sale/ buy transactions are recorded on the ledger in real time. However, this entails long histories of ownership for actively traded corporations demanding greater processing activity and computing power. ${ }^{186}$

The trading cycle ends with settling trades that took place on stock exchanges. A smart contract executes changes in custody of a security, by modifying the ledger, once it has verified that both parties have met

\footnotetext{
177 Bramhall (n 161) 7.

${ }^{178}$ Morris and Glodstein (n 18) 8.

179 Ibid.

${ }^{180}$ CII Letter 31 Jan 2019 (n 3) 5.

${ }^{181}$ Mills and others (n 152) 14.

${ }^{182}$ Depository Trust and Clearing Cooperation, Embracing Disruption: Tapping the Potential of Distributed Ledgers to Improve the Post-Trade Landscape (Cm 2016) 14.

183 Geis (n 32) 37-38.

${ }^{184}$ Hakes (n 24) 730-731.

185 Blockchain may disrupt back-office operations of banks/ brokers pertaining to post-trade recordkeeping and execution, but not supplant their business model. See CII Letter 31 Jan 2019 (n 3) 6.

186 Geis (n 32) 39.
} 
their obligations. ${ }^{187}$ This replaces DTC's function of settling trades (making book-entry security movements from and to the accounts of participating brokers/ banks). Said differently, the existing plumbing system would be overhauled.

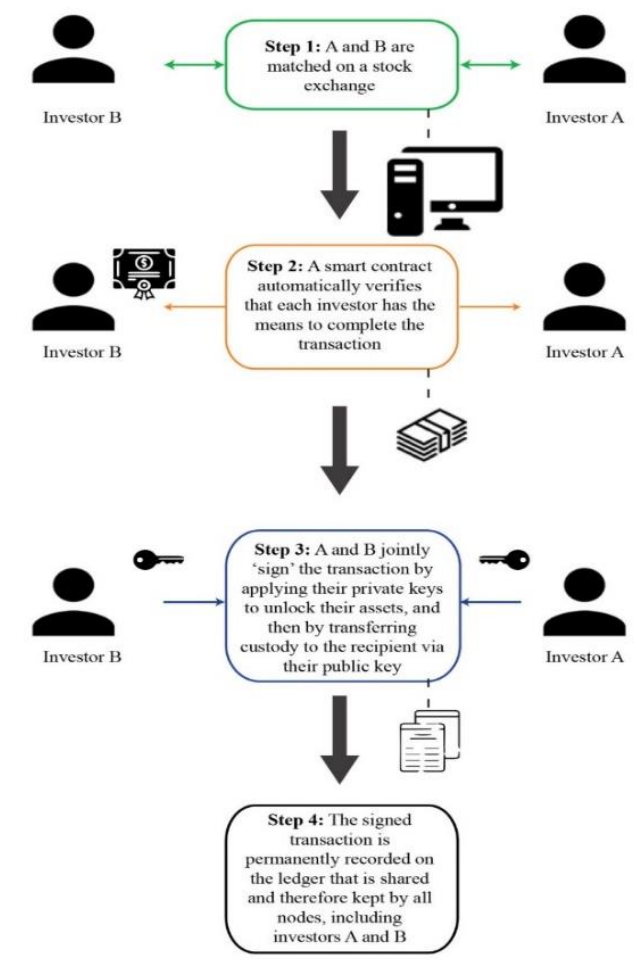

Figure 3: Clearing and Settlement on Blockchain

Under the proposed model, a recipient of a given token holds direct custody due to streamlining of existing custodial arrangements. ${ }^{188}$ However, direct custody may not necessarily equate to direct ownership of a token. Debate over ownership status of a token is beyond the scope of this contribution. It suffices to say that some purport that possession of a token entails direct ownership, ${ }^{189}$ while others foresee that digitized securities cannot yield property rights. ${ }^{190}$ If any, this analysis may have to be taken in light of UCC and DGCL provisions on property rights.

${ }^{187}$ CII Letter 31 Jan 2019 (n 3) 4-5.

${ }^{188}$ Since the recipient holds direct custody it is likely that the securities intermediaries' current obligation to obtain and maintain securities on behalf of the entitlement holder (under section 8-504) would cease, along with the securities intermediaries' duty to follow due care (at minimum) when preforming such obligation. See Del. Code Ann. tit. 6, § 8-504 (West).

${ }^{189}$ Bramhall (n 161) para 5, 25.

190 Tatiana Cutts, 'Bitcoin Ownership and its Impact on Fungibility' (COINDESK, 14 June 2015) <https://www.coindesk.com/bitcoin-ownership-impact-fungibility> accessed 2 December 2019. 
Moreover, securities on blockchain are said to be traceable because the addresses containing tokens are visible to gatekeepers. ${ }^{191}$ By matching shareholders' private keys (login credentials) to their addresses (a product of their public key), gatekeepers are able to link ownership of each token to its holder. ${ }^{192}$ This introduces transparency which the fungible bulk system lacks and for which complexities arise in the voting system. However, the efficacy of tracing shares hinges on resolving technical design issues, and regulatory gaps.

\subsection{Technical Design Issues}

The ability to trace shares assumes that shareholders are skilled enough to manage and secure private keys. Effective management is imperative, because if a private key associated to a particular token residing within an address is lost or compromised then that token is irrevocably lost. ${ }^{193}$ Hence, shareholders would incur monetary loss without recourse. Even more seriously, loss may lead to fraud or takeover of assets contained in the address. ${ }^{194}$

That said, investors may lack technical sophistication needed to effectively manage private keys. One may even expect investors to voluntarily deposit their tokens with custodians, who may decide to hold them in addresses containing pooled assets. ${ }^{195}$ However, doing so compromises blockchain's goal of creating a clear chain of title for every unit of stock. ${ }^{196}$ Investors engaging with proxy advisors may, alternatively, grant them access to their private key for management and safekeeping.

Achieving strong safety features is a challenging undertaking that depends on various design choices (e.g. strength of cryptography). ${ }^{197}$ Private permissioned blockchain attempts to achieve this by binding the identity of public keys to individual or corporate identities. This on its own may not prove to be sufficient, gatekeepers may want consider best practices in information security that extend beyond cryptography. ${ }^{198}$

Other design issues must be carefully considered prior to adoption. Recall that a private permissioned blockchain empowers a single platform operator (gatekeeper) to control changes to the ledger, grant access to the system, inter alia. This resembles, to a large extent, existing arrangements. It is possible that gatekeepers charge rents for access and services, and that they may fail to treat participants evenhandedly. This undermines aims of improved integrity and efficiency, ${ }^{199}$ and creates a need for

\footnotetext{
${ }^{191}$ Bramhall (n 161) 7.

192 Mills and others (n 152) 12.

193 Bramhall (n 161) 7-8.

${ }^{194}$ Mills and others (n 152) 24.

195 Changpeng Zhao, 'CZ on Centralization Vs. Decentralization' (Binance Blog, 12 February 2019) <www.binance.com/en/blog/301982828007075840/CZ-on-Centralization-Vs-Decentralization?ref=tokendaily> accessed 29 November 2019.

${ }^{196}$ Bramhall (n 161) 7-8.

${ }^{197}$ Mills and others (n 152) 24.

198 Ibid.

${ }^{199}$ Ibid 31.
} 
regulating prices charged and imposing enforcement measures (e.g. threat of sanction or expulsion for misbehavior). ${ }^{200}$

Further, having information stored on a limited number of nodes controlled by gatekeepers concentrates operational risk. ${ }^{201}$ The system could fail due to internal malfunction, external threats (e.g. deliberate attacks or if a participant's system shut downs), even a surge in trading volume may overwhelm operations. ${ }^{202}$ Unless resilience is ensured, the adoption of blockchain may well be rejected - for unsafe operation can damage the broader stability of the financial market. ${ }^{203}$

Other concerns relate to scalability - whether blockchain can accommodate hundreds of millions of daily trades. While a private blockchain decreases latency relative to a public blockchain (i.e. time taken for an order instruction to be recorded on the ledger) by removing the consensus process, other aspects of scalability are not clear. ${ }^{204}$ Again, implementation will be dismissed by public authorities and intermediaries if blockchain cannot provide speedy and reliable services.

\subsection{Regulatory Gap}

Given the existing regulatory environment, the adoption of blockchain plumbing and voting is impossible. Unless existing SEC Rules and/ or DGCL provisions are restructured, only incremental changes can be made to the voting system. As such, this subsection explores how SEC Rules may permit disintermediation of a registered clearing agency and central depository (DTC and NSCC) to facilitate direct holding, and thereafter direct voting. ${ }^{205}$

Since the establishment of DTC in the 1970s, SEC has concentrated more power in national CSPs. It approved a rule proposed by major stock exchanges requiring issuers to make their securities DTC eligible ${ }^{206}$ prior to listing; ${ }^{207}$ it empowered DTC to refuse security withdrawal requests by issuers; ${ }^{208}$ and it prohibited issuers from passing bylaw amendments making their securities ineligible for DTC ownership and book-entry services. ${ }^{209}$

${ }^{200}$ Geis (n 32) 38.

201 Yermack (n 173) 10.

${ }^{202}$ Morris and Glodstein (n 18) 29.

${ }^{203}$ Mills and others (n 152) 33.

${ }^{204}$ Ibid 22.

${ }^{205}$ This contribution does not purport to address all possible legal issues arising from or in relation to blockchain CSPs and voting processes, nor does it feature all laws and regulations that may relate thereto.

${ }^{206}$ A security is DTC eligible when it qualifies for being held at DTC and for being traded and serviced through its electronic book entry system. For instance, the issuance must meet the meaning of 'financial asset' under UCC, fulfill or be exempt from certain requirements under SEC Rules, and have a CUSIP number. See Morris and Glodstein (n 18) 34.

${ }^{207}$ Securities Transactions Settlement, 69 FR 12922-01.

${ }^{208}$ Self-Regulatory Organizations; The Depository Trust Company; Order Granting Approval of a Proposed Rule Change Concerning Requests for Withdrawal of Certificates by Issuers, 68 FR 35037-01.

${ }^{209}$ Proposed Rule: Issuer Restrictions or Prohibitions on Ownership by Sec. Intermediaries, Release No. 49804 (June 4, 2004). 
These rules intend to stop issuers from reverting to manual CSPs, and thus, protect the financial market from problems experienced pre-1970s paper crises: inefficiency, risk, and added cost in CSPs. However, such rules also bar any alternative to DTC share provenance - including blockchain's electronic substitute to paper certificates. ${ }^{210}$

To permit blockchain share provenance, SEC would need to grant regulatory relief from prevalent CSPs. ${ }^{211}$ That is, SEC would set regulatory standards that issuers and their transfer agents must meet in order to qualify for relief pertaining but not limited to: consenting to making securities DTC eligible; ${ }^{212}$ prohibition on withdraw of securities by board of directors and shareholder resolution; ${ }^{213}$ prohibition on passing of corporate bylaws permitting alternative certificated transfers; ${ }^{214}$ performing strict CSPs such as novation, netting, and final settlement through intermediaries in two days $(\mathrm{T}+2) ;{ }^{215}$ and registering with SEC as a transfer or clearing agency. ${ }^{216}$

If relief is indeed granted, how could the transition from an IHS to a direct one look like? Tokens representing securities would be originally issued in electronic form to investors (i.e. they are granted private keys associated to an address in which issued tokens reside). Transfer of ownership of a single token would require re-registration of that token in the name of the buying investor (new owner) ${ }^{217}$ Like paper-based holding, securities need not be physically isolated and held in unidentifiable bulk with DTC. ${ }^{218}$ In that manner, blockchain creates a fully electronic version of paper certificates but without the risks and costs that prompted the paper crisis.

Further, existing issuers could elect to withdraw their fungible bundle of securities from DTC and record ownership digitally on blockchain. As for corporations going public, they could elect to place issued securities directly on blockchain as opposed to having them DTC eligible. ${ }^{219}$ To be sure, this transition requires coordination between blockchain CSPs and existing arrangements. Otherwise, significant costs may arise from reconciling siloed solutions and dissimilar standards. An outcome that would clearly deter policymakers from permitting adoption..$^{220}$

\footnotetext{
${ }^{210}$ CII Letter 31 Jan 3019 (n 3) 4.

${ }^{211}$ CII Letter 31 Jan 2019 (n 3) 4-5.

212 Self-Regulatory Organizations; American Stock Exchange, Inc.; Boston Stock Exchange, Incorporated; Chicago Stock Exchange Incorporated; National Association of Securities Dealers, Inc.; New York Stock Exchange, Inc.; the Pacific Stock Exchange Incorporated; Philadelphia Stock Exchange, Inc., Order Approving on an Accelerated Basis Proposed Rule Changes Regarding Depository Eligibility Requirements, 60 FR 30909-01

213 Self-Regulatory Organizations; The Depository Trust Company; Order Granting Approval of a Proposed Rule Change Concerning Requests for Withdrawal of Certificates by Issuers, 68 FR 35037-01.

${ }^{214}$ Proposed Rule: Issuer Restrictions or Prohibitions on Ownership by Sec. Intermediaries, Release No. 49804 (June 4, 2004).

${ }^{215}$ Securities Transaction Settlement Cycle, 82 FR 15564-01.

${ }^{216}$ Regulation of Clearing Agencies, Release No. 16900 (June 17, 1980).

${ }^{217}$ Mills and others (n 152) 25.

218 Geis (n 32) 40.

${ }^{219}$ CII Letter 31 Jan 2019 (n 3) 5.

${ }^{220}$ Embracing Disruption (n 182) 2.
} 


\section{Overhaul of Existing Proxy Voting System}

\subsection{Envisioning Proxy Voting on Blockchain}

Once regulatory relief is granted, blockchain traceable shares could be used in the voting context to resolve voting pathologies. While share identification is currently extremely difficult (e.g. in appraisal claims), blockchain could allow every unit of stock to have a clear chain of title identifying current and prior owners. ${ }^{221}$ Needless to say, fundamental change will not come easy. It requires substantial resources and effort, and it will likely encounter resistance from incumbents (e.g. Broadridge) who profit from inefficiencies endemic to the current voting system. ${ }^{222}$

Prior to examining how blockchain may resolve voting pathologies, it useful to understand how the voting process could work on blockchain (see figure 4). We focus on the following aspects in order to illustrate how streamlining the voting process may benefit shareholder voting:

a. Construction of blockchain: Following our initial model, blockchain is permissioned (only the trusted gatekeeper can enter its content) and private (viewable only by the corporation and its transfer agent, shareholders and their proxy advisors, and regulators). ${ }^{23}$ The technology records each shareholder's holdings as of the record date - which would ideally be fixed much closer to the meeting date than currently allowed by DGCL (i.e. ten-sixty days). ${ }^{224}$

Under the existing voting system, a long time gap is vital for moving up and down the chain of intermediaries to find the approximate number of beneficial owners. Conversely, blockchain records the exact number of shareholders eligible to vote without having to take lengthy steps. This smooths operational complexities, and thus, mitigates errors and costs currently incurred by issuers and their owners.

b. Distribution of proxy materials: Closer to the meeting date, the gatekeeper uploads proxy materials for shareholders to view. ${ }^{25}$ This ensures that all shareholders have instant and simultaneous access to proxy materials, and hence, to voting rights. Whereas, under existing arrangements materials often do not reach some shareholders in time for them to vote because intermediaries are required to work under tight deadlines amid cumbersome processes. ${ }^{26}$ Thus blockchain offers a far less expensive voting process that warrants eligible shareholders their entitlements (e.g. voting rights, right to proxy materials, etc.).

\footnotetext{
${ }^{221}$ Geis (n 32) 40.

${ }^{222}$ CII Letter 8 Nov 2018 (n 3) 4.

${ }^{223}$ Ibid 5.

${ }^{224}$ Del. Code Ann. tit. 8, § 213 (West).

${ }^{225}$ CII Letter 8 Nov 2018 (n 3) 5.

${ }^{226}$ Kahan and Rock (n 30) 1249.
} 
c. Vote allocation and execution: As of the record date but before a shareholders meeting, the gatekeeper allocates tokenized voting rights (or votecoins) ${ }^{227}$ to shareholders' addresses on a pro rata basis. ${ }^{228}$ As such, shareholders know precisely how many votes they are entitled to cast.

Additionally, gatekeepers authenticate the identity of voters (shareholders or their proxy advisors) by requiring provision of their personal identification outside the chain. The gatekeeper then records proof of authentication on the chain for voting instructions to be executed. ${ }^{229}$ During a predetermined voting period, shareholders or proxy advisors (with access to shareholders' private keys) transfer votecoins corresponding to their voting preference to an address, which automatically counts votes. ${ }^{230}$

Noticeably, blockchain makes redundant the functions of material dissemination and voting solicitation typically performed by proxy service providers. ${ }^{231}$ This promises issuers massive cost savings, typically paid to Broadridge for its communication services. ${ }^{232}$

d. Vote tabulation: Tabulation would occur in real time. As shareholders or proxy advisors cast allotted votes, ${ }^{233}$ blockchain immediately relays back voting instructions and verification that votes are counted. In turn, each shareholder has immediate and accurate end-to-end confirmation on how their shares were voted. $^{234}$ Of course, the corporation and other shareholders would not be able to see how many

227 Yermack (n 173) 23.

${ }^{228}$ Kahan and Rock (n 30) 1255.

${ }^{228}$ Nord (n 33) 732.

${ }^{229}$ CII Letter 8 Nov 2018 (n 3) 5.

230 Other permissioned blockchain models propose that shareholders may transfer their votecoins to addresses of proxy advisors. However, doing so would deprive the shareholder from knowing exactly how her shares were voted since the dispatched votecoins may be commingled in the proxy's account. Essentially, the concept of fungible bulk would be replicated on blockchain. See Nord (n 33) 732.

${ }^{231}$ Having the voting solicitation function of proxy service providers diminish indicates that broker's/ bank's role and in fact obligation to exercise corporate rights on behalf entitlement holders (under section 8-506) would also likely diminish, along with these securities intermediaries' duty to follow due care standards (at minimum) when performing the said obligation. See Del. Code Ann. tit. 6, § 8-506(2) (West).

232 n 29.

233 Currently a fiduciary standard governs the conduct of proxy advisers under Rule 206(4)-6 of the Investment Advisers Act of 1940 - whereby proxy advisors owe their clients duties of care and loyalty with respect to all services undertaken on the client's behalf, including proxy voting. See Sec. \& Exch. Comm'n v. Capital Gains Research Bureau, Inc., 375 U.S. 180, 181, 84 S. Ct. 275, 277, 11 L. Ed. $2 d 237$ (1963). To be sure, Rule 206(4)-6 requires a proxy advisor that exercises voting authority over clients' proxies to adopt "reasonably designed" policies/procedures that ensure that the advisor votes in the best interest of its clients; to disclose to clients' information about such policies/procedures; and likewise to disclose how clients may obtain information on how the advisor has voted. Otherwise, the statute proclaims that the advisors' act is fraudulent, deceptive, or manipulative within the meaning of Section 206(4) of the said Act. See US Securities and Exchange Commission, 'Final Rule: Proxy Voting by Investment Advisers' (The SEC is adopting a new rule and rule amendments under the Investment Advisers Act of 1940, Washington DC, February 2003) <https://www.sec.gov/rules/final/ia-2106.htm\#P43_3923> accessed 28 June 2020. Case law furthers that a breach of this fiduciary duty may void an investment advisers' contract. See Transamerica Mortg. Advisors, Inc. (TAMA) v. Lewis, 444 U.S. 11, 11, 100 S. Ct. 242, 243, 62 L. Ed. 2d 146 (1979). Notably, under the proposed blockchain system this fiduciary duty imposed upon proxy advisors is unlikely to change because it would continue to protect the interests of advisory clients/ shareholders regardless of the system in place.

${ }^{234}$ CII Letter 8 Nov 2018 (n 3) 6. 
shareholders have voted. Once the voting period ends, the blockchain would immediately report aggregated results to the corporation and shareholders. ${ }^{235}$

Vote verification in this manner ensures that only owners of securities as of the record date, are truly those voting. There would be no need to worry about former owners or unrelated parties casting fraudulent votes. ${ }^{236}$ Such transactions, would simply be rejected as invalid. Further, the immutable nature of the stock ledger guarantees certainty and accuracy in vote processing since transactions cannot be removed, but only updated. Evidently, these features lack in the existing system where tabulators attempt to resolve inaccurate votes in a rudimentary manner. ${ }^{237}$

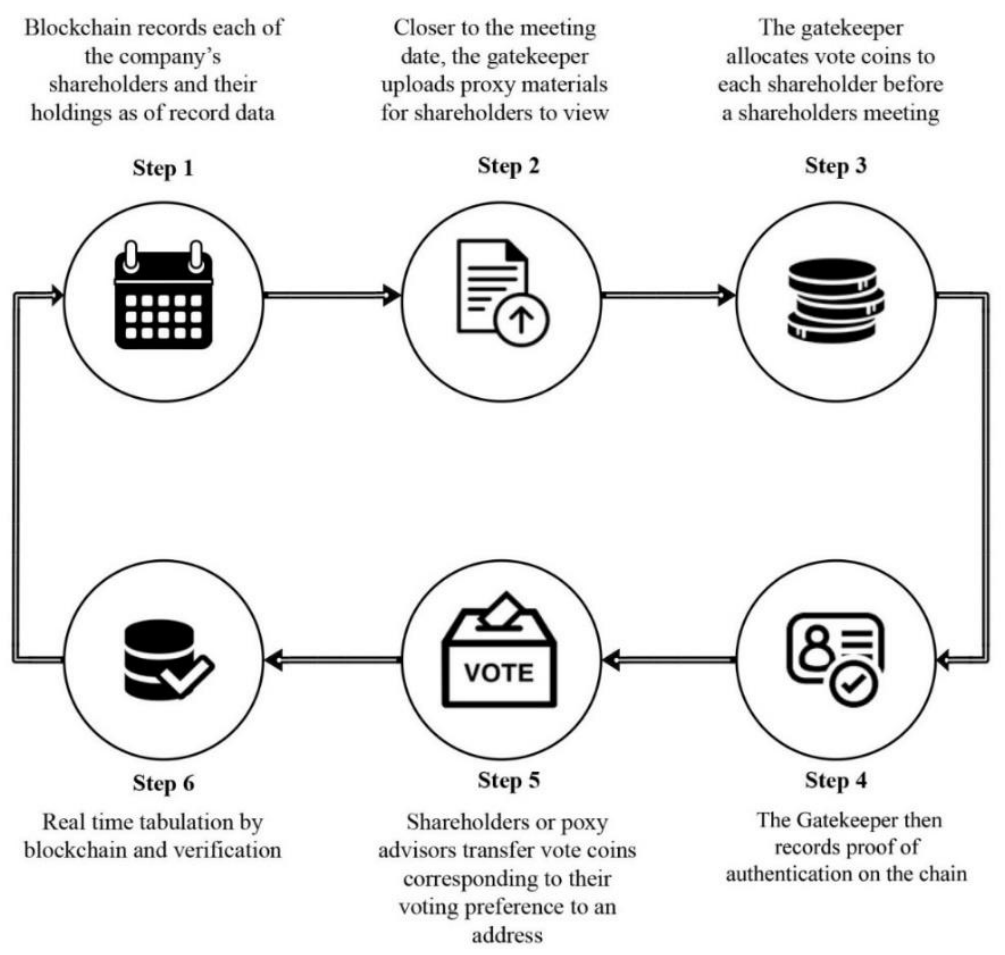

Figure 4: Voting on Blockchain

\subsection{Impact on Shareholder Voting}

${ }^{235}$ DGCL provisions may need to be amended to provide for the proposed shortened period between the record date and the meeting date, to grant issuers' relief for their obligation to appoint tabulators, inter alia.

236 Geis (n 32) 42.

${ }^{237}$ Nord (n 33) 718. 
Once one understands how blockchain operates in the voting context, it becomes easy to spot how the four pathologies of voting are eliminated or mitigated in favor of investors. The following subsection describes how investors may enjoy quicker, more accurate, and secure voting.

\subsubsection{Pathologies of Complexity}

The opacity of the IHS makes it procedurally difficult for shareholders to confirm how theirs shares have been voted. While, DGCL continues to condition shareholders' accessibility to certain legal rights (e.g. appraisal rights) upon this confirmation. With blockchain's custody ledger, shareholders could supply evidence of their share provenance and voting decisions as necessary. ${ }^{238}$ This facilitates shareholders' access to legal rights, and thus, boosts the overall health and fairness of capital markets.

In the context of appraisal rights, courts need not probe about Cede casting enough non-positive votes to support all claims, nor need they worry about how to apportion eligible shares among multiple claimants without knowing exactly whose specific shares were voted appropriately. ${ }^{239}$ That said, appraisal arbitrage would be curtailed and its adopters would find it difficult to insist that their votes are covered by Cede's total dissenting/ abstaining votes.

Moreover, current complexities associated to share identification by latecomers are mitigated. By narrowing the voting gap (i.e. time between the record and meeting dates) a purchasing shareholder could obtain the vote much closer to the meeting date, retain the vote, and offer evidence for nonpositive voting. ${ }^{240}$ Thus, there would be less need for courts to debate how late purchased shares were voted by others - as in the Transkaryotic case. ${ }^{241}$

Some tricky situations may persist. Imagine that a corporation announces a merger on May $1^{\text {st }}$, the record date is June 15 , and votes are tallied over 24-hours from the record date. ${ }^{242}$ Shareholder A votes her 10 shares on May $31^{\text {st }}$ but sells them to shareholder B on June $2^{\text {nd }}$. In turn, shareholder B retains the right to revote those 10 shares against the deal, and to resurrect an appraisal claim. However, to avoid confusion on how those 10 shares were voted verification protocols need to additionally screen-out the selling shareholder's earlier votes. ${ }^{243}$ Otherwise, this could drown out benefits of voting with traceable shares.

\subsubsection{Pathologies of Ownership}

A clear chain of custody forgoes uncertainties as to who owns a specific share of stock, and therefore, the negative side effects that follow therefrom. In the context of margin lending, transparency of share ownership eliminates the problem of over-voting.

\footnotetext{
${ }^{238}$ CII Letter 31 Jan 2019 (n 3) 8.

${ }^{239}$ n 21-23.

${ }^{240}$ Geis (n 32) 45.

241 n 22-23.

242 Geis (n 32) 41.

${ }^{243}$ Ibid 45.
} 
Recall, that a margin loan transfers legal title and voting rights from lending investors to borrowers (e.g. institutional investors). ${ }^{244}$ A broker effecting a margin loan, on behalf of a lending investor, cannot reflect the loan on its books due to share fungibility. Problematically, the broker may end up submitting more than $100 \%$ of its share allotment.

Intuitively, blockchain would record ownership transfers for the exact number of shares that are on loan. The gatekeeper would then allocate votecoins to lenders and borrowers based on their exact equity holdings. ${ }^{245}$ Stock loans would become transparent - perhaps even providing notice to shareholders and management regarding redistribution of voting rights. ${ }^{246}$

Further, the elimination of over-voting foregoes rudimentary reconciliation methods by brokers/ banks. Current reconciliation methods disregard inaccuracies in vote counts at the beneficial owner level, albeit ensure that total votes submitted to tabulators match brokers/ banks' DTC position. ${ }^{247}$ That is, brokers/ banks act as if votes belong to them (not beneficial owners). ${ }^{248}$ Blockchain would place voting rights back in the hands of true owners - those whose voting intent is critical to the fate of a corporation and is meant to maximize shareholder value.

That said, investors may regain confidence in the integrity and accuracy of the voting system which may bolster participation rates in corporate governance (e.g. through greater activity in shareholder proposals). ${ }^{249}$ However, greater access to information may not improve participation due to shareholder apathy. Most Americans passively invest in mutual funds, and thus cede active management with little care about the underlying stock owned by their respective funds. Hence, they would certainly not care about corporate governance issues at individual portfolio companies. ${ }^{250}$ Even shareholders who actively manage their investments are notoriously uninformed. ${ }^{251}$

Theoretically, a perfectly informed shareholder undermines the rationale behind a prudent board representation. ${ }^{252}$ Insulated from shareholder influence, expert directors and specialists enable an efficient running of the corporation in favor of owners. Conversely, greater shareholder participation may hinder the board's strategic and managerial roles.

\subsubsection{Pathologies of Misalignment}

Intermediated stockholding and voting systems necessitate an early record date for determining and executing voting rights ahead of shareholder meetings, but open room for empty voting (voting rights

\footnotetext{
${ }^{244}$ n $23-25$

${ }^{245}$ CII Letter 8 Nov 82018 (n 3) 5.

${ }^{246}$ Yermack (n 173) 24.

${ }^{247} \mathrm{n} 24$.

${ }^{248}$ CII Letter 8 Nov 2018 (n 3) 4.

${ }^{249}$ Geis (n 32) 42; CII Letter 8 Nov 2018 (n 3).

${ }^{250}$ Nord (n 33) 745.

${ }^{251}$ Lynn A Stout, 'Are Stock Markets Costly Casinos - Disagreement, Market Failure, and Securities Regulation' (1995)

81 Virginia Law Review 611, 710.

${ }^{252}$ Kraakman and others (n 55) 12-13.
} 
are exercised without economic exposure). ${ }^{253}$ So far, the market has endured significant anomalies arising therefrom without recourse to effective solutions. ${ }^{254}$

Where voting is done without intermediaries under blockchain, the need for an early record date becomes superfluous. Indeed, fixing the record date closer to the meeting date would mitigate empty voting. A shorter time gap would ensure that voting power is linked to share ownership for longer periods of time, and hence, there would be fewer opportunities for extraneous votes to be sold or manipulated..$^{255}$

This may deter some of the undesirable outcomes of empty voting, ${ }^{256}$ including: (i) diminishing a company's share value whether done intentionally as a tactic or unintentionally due shareholder apathy; and (ii) safeguarding the interests of one group of shareholders at the expense of another disempowered group as in the Mylan/ King merger. ${ }^{257}$

To be clear, reducing the time gap would only address part of the problem. Activist shareholders and hedge funds may still go on buying sprees in order to steer election outcomes, as the voting date approaches. They would buy and retain shares (and so votes too), whilst hedging away the economic risks derived from share ownership (using swaps or other derivative transactions). ${ }^{258}$ Consequently, sophisticated tactics such as those deployed by Perry in the Mylan/ King merger would not be curtailed after all. Perhaps more comprehensive solutions would be needed to eliminate empty voting.

\subsubsection{Financial Costs}

The aforesaid analysis indicates that issuers and investors will save costs by ridding of expensive reconciliation methods and proxy solicitation services. ${ }^{259}$ It is true, that we had presaged that appointing a central gatekeeper (operating the platform) may replicate existing bereft of competition and susceptibility to concentrated risks of failure. However, if SEC grants regulatory relief for corporations developing blockchain solutions, that would reduce entry barriers. ${ }^{260}$ Prices would be set by forces of demand and supply whilst competition would be enhanced among platform operators.

\section{Conclusion}

The creation of the IHS was an immediate response to risks associated to paper certificated transfers. Indeed, the current system ensures some degree of safety and efficiency. However, it compromises the direct relationship between corporations and their true owners - as voting rights can only be exercised through intermediaries constituting the IHS. This proxy voting mechanism is rife with procedural

\footnotetext{
${ }^{253} \mathrm{Hu}$ and Black (n 115) 1015-1017.

${ }^{254}$ CII Letter 8 Nov 2018 (n 3) 4.

255 Nord (n 33) 733.

${ }^{256}$ Geis (n 32) 42.

${ }^{257}$ n 27-28

${ }^{258}$ Geis (n 32) 42.

${ }^{259}$ Blockchain in Capital Markets (n 140) 20.

${ }^{260}$ CII Letter 31 Jan 2019 (n 3) 8.
} 
complexity and suffers from lack of share ownership transparency. Consequently, significant voting pathologies arise.

Demands for change are compelling, especially with the prospect of blockchain offering a clear chain of title throughout the settlement cycle. Without fungible bulk, direct voting on blockchain is enabled. This dramatically streamlines voting processes, reduces monetary costs, and mitigates/ eliminates other pathologies illustrated by over-voting or vote manipulations.

However, reforms in the US stockholding and voting systems based on blockchain are conceptual. Adoption remains contingent on the resolution of regulatory gaps and technical design issues. Current SEC rules preclude any alternative share provenance system, and thus, regulatory relief is necessary if blockchain is to be adopted. As for technical design issues, blockchain is still in its infancy and requires further study into its compatibility with the financial market (e.g. resilience, security, etc.). Even if, regulatory relief is granted but the technology is immature that could harm the health of the overall financial market.

These findings are the result of an endeavor to investigate technical, functional, and legal aspects of blockchain. Available considerations on the adoption of blockchain as a pure recordkeeping mechanism, and in the context of stockholding and voting vary in their outcomes and in their extremity. However, available variation enabled the building of a holistic and multi-angled view on what blockchain stockholding and voting might look like. The proposed infrastructure goes beyond a basic framework by utilizing available variations. It makes interconnections between blockchain's technological features, CSPs, and voting logistics all whilst making comparisons to the pre-1970s direct and IHS - something which extant literature lacks.

\section{Bibliography}

Bower J L and Paine L S, The Error at the Heart of Corporate Leadership (Harvard Business School Publishing Corporation 2017).

Bramhall P, ‘Blockchain Isn't Always the Solution (or Why Tokenizing Equity Securities is not the Answer to the Proxy Voting Problem)' (2019) Working Paper 3393774

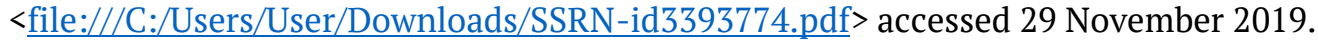

Broadridge, 'Portfolio Securities Voting' (Broadridge Financial Solutions) < $\underline{w w w . b r o a d r i d g e . c o m / f i n a n c i a l-~}$ services/asset-management/institutional-investors/enhance-and-simplify-portfoliomanagement/portfolio-securities-voting> accessed 29 November 2019.

Castillo del M, '\$11 Trillion Bet: DTCC to Process Derivatives With Blockchain Tech' (COINDESK, 21 December 2017 <https://www.coindesk.com/11-trillion-bet-dtcc-clear-derivatives-blockchain-tech> accessed 29 November 2019. 
Council of Institutional Investors, The OBO/NOBO Distinction in Beneficial Ownership: Implications for Shareowner Communications and Voting (Cm S7-14-10, February 2010).

Council of Institutional Investors, 'Re: File Number 4-725 Roundtable on the Proxy Process, and File Number S7-24-16 (Universal Proxy)' (Council of Institutional Investors 8 November 2018) <www.cii.org/files/20181108\%20CII\%20Letter\%20for\%20SEC\%20Proxy\%20Roundtable.pdf> accessed 29 November 2019.

Council of Institutional Investors, 'Re: File Number 4-725 Roundtable on the Proxy Process' (Council of Institutional Investors 31 January 2019) <www.sec.gov/comments/4-725/4725-4864575-177347.pdf> accessed 29 November 2019

Daniels A, 'Blockchain \& Shareholder Voting: A Hard Fork for $21^{\text {st }}$ Century Corporate Governance' [2018] 21 University of Pennsylvania Journal of Business Law 405.

Depository Trust and Clearing Cooperation, Embracing Disruption: Tapping the Potential of Distributed Ledgers to Improve the Post-Trade Landscape (Cm 2016) 14.

Donald D, 'The Rise and Effects of the Indirect Holding System: How Corporate America Ceded its Shareholders to its Intermediaries' (2007) University of Frankfurt Institute for Law and Finance Draft Paper 1017206 <file:///C:/Users/User/Downloads/SSRN-id1017206.pdf> accessed 29 November 2019.

Donald D, 'Heart of Darkness: The Problem at The Core of the US Proxy System and Its Solution' [2011] 6 Virginia Law \& Business Review Association 41.

Cutts T, 'Bitcoin Ownership and its Impact on Fungibility' (COINDESK, 14 June 2015) <https://www.coindesk.com/bitcoin-ownership-impact-fungibility> accessed 2 December 2019.

Garvin T L, 'The Changed (and Changing) Uniform Commercial Code' (1999) 26 Florida State University Law Review 285.

Geis G, 'Traceable Shares and Corporate Law' (2018) 113 Northwestern University Law Review 1 (forthcoming).

Greco P, ‘Blockchain Implementation in Today's Security Settlement Process' (2018) <https://thedailycpa.com/wp-content/uploads/2019/05/Blockchain-Implementation-in-Todays-SecuritySettlement-Process-2.pdf> accessed 29 November 2019.

Hakes R A, 'UCC Article 8: Will the Indirect Holding of Securities Survive the Light of Day' [2002] 35 Loyola of Los Angeles Law Review 661.

Hu H TC and Black B, 'Empty Voting and Hidden (Morphable) Ownership: Taxonomy, Implications, and Reforms’ [2006] 61 The Business Lawyer 1011. 
International Corporate Governance Network, 'Cross-Border Voting' (International Corporate Governance Network, July 2014) <www.icgn.org/policy/viewpoints/cross-border-voting> accessed 27 November 2019.

Kahan M and Rock E, 'The Hanging Chads of Corporate Voting' [2008] 96 The Georgetown Law Journal 1227.

Kearney K, 'Proxy.gov: A Proposal to Modernize Shareholder Lists and Simplify Shareholder Communications' (2015) 37 Hastings Communications and Entertainment Law Journal 391.

Kelly J, 'Computershare teams up with start-up SETL on blockchain project' (Reuters, 28 April 2016) <www.reuters.com/article/us-securities-blockchain-computershare/computershare-teams-up-withstart-up-setl-on-blockchain-project-idUSKCNOXP1NL> accessed 29 November 2019.

Kraakman R and others, The Anatomy of Corporate Law: A Comparative and Functional Approach (3rd edn, Oxford University Press 2017).

Laster J T 'The Block Chain Plunger: Using Technology to Clean Up Proxy Plumbing and Take Back the Vote' (Keynote Speech to the Fall 2016 meeting of the Council of Institutional Investors, 29 September 2016) <www.cii.org/files/09_29_16_laster_remarks.pdf> accessed 27 November 2019.

Latham \& Watkins, 'M\&A: Deal Commentary' (Latham \& Watkins April 2007) pt Record Date vs. Meeting Date <www.lw.com/upload/pubContent/pdf/pub1878_1.Commentary.Empty.Voting.pdf> accessed 29 November 2019.

Mainelli M and Milne A, 'The Impact and Potential of Blockchain on the Securities Transaction Lifecycle' (2016) SWIFT Institute 48 <www.swiftinstitute.org/wp-content/uploads/2016/05/The-Impact-andPotential-of-Blockchain-on-the-Securities-Transaction-Lifecycle_Mainelli-and-Milne-FINAL-1.pdf> accessed 29 November 2019.

Mann R J and others, Comprehensive Commercial Law: 2017 Statutory Supplement (Wolters Kluwer Law \& Business, 2017).

Mills D and others, 'Distributed Ledger Technology in Payments, Clearing, and Settlement' (2016) Board of Governors of the Federal Reserve System Working Paper 2881204 <file://C:/Users/User/Downloads/SSRN-id2881204.pdf> accessed 29 November 2019.

Mooney C W, 'Beyond Intermediation: A New (FinTech) Model for Securities Holding Infrastructures' (2019) University of Pennsylvania Law School 2098.

Morris V B and Glodstein S Z, The Lifecycle of a Security (Lightbulb Press, Inc. 2010).

Nord S J, 'Blockchain Plumbing: A Potential Solution for Shareholder Voting' [2019] 21 University of Pennsylvania Journal of Business Law 706.

OECD (2011), The Role of Institutional Investors in Promoting Good Corporate Governance, Corporate Governance, OECD Publishing. 
Oxford Economic Research Associates, 'Corporate Action Processing: What are the Risks?' (Sponsored by Depository and Trust Clearing Corporation, Oxford Economic Research Associates May 2004) <www.oxera.com/wp-content/uploads/2018/03/Corporate-action-processing.pdf>

PAECH P, Cross-Border Issues of Securities Law: European Efforts to Support Securities Markets with a Coherent Legal Framework (Requested by the European Parliament's Committee on Economic and Monetary Affairs, Cm 464.416, 2011).

Panisi F and others, 'Blockchain and Public Companies: A Revolution in Share Ownership Transparency, Proxy-Voting and Corporate Governance?’ [2019] 2.2 Stanford Journal of Blockchain Law and Policy 1.

Ryan R and Donohue M, 'Securities on Blockchain' (2017) 73 Business Lawyer 85.

Seretakis A L, 'Blockchain Securities Markets and Central Banking' (2017) Trinity College Dublin Working Paper 3007402 <file:///C:/Users/User/Downloads/SSRN-id3007402.pdf> accessed 29 November 2019.

Song W, 'Bullish on Blockchain: Examining Delaware's Approach to Distributed Ledger Technology in Corporate Governance Law and Beyond' (2017) 8 Harvard Business Law Review 9.

Steyer R, 'Mylan and Icahn Turn Up the Volume' (TheStreet, 22 December 2004) <www.thestreet.com/story/10200481/1/mylan-and-icahn-turn-up-the-volume.html> accessed 29 November 2019.

Steyer R, 'New Player Joins Mylan-King Fray' (TheStreet, 29 November 2004) $<$ www.thestreet.com/story/10196467/1/new-player-joins-mylan-king-fray.html> accessed 29 November 2019.

Stout L A, 'Are Stock Markets Costly Casinos - Disagreement, Market Failure, and Securities Regulation' (1995) 81 Virginia Law Review 611.

Toole M and others, 'The First Block in the Chain: Proposed Amendments to the DGCL Pave the Way for Distributed Ledgers and Beyond' (Harvard Law School Forum on Corporate Governance and Financial Regulation, 2017) <https://corpgov.law.harvard.edu/2017/03/16/the-first-block-in-the-chain-proposedamendments-to-the-dgcl-pave-the-way-for-distributed-ledgers-and-beyond/> accessed 29 November 2019.

US Securities and Exchange Commission, 'Final Rule: Custody of Investment Company Assets with a Security Depository' (The SEC is adopting amendments to rule 17f-4 under the Investment Company Act of 1940, Washington DC, February 2003) <https://www.sec.gov/rules/final/ic-25934.htm\#I> accessed 28 June 2020. 
US Securities and Exchange Commission, 'Final Rule: Proxy Voting by Investment Advisers' (The SEC is adopting a new rule and rule amendments under the Investment Advisers Act of 1940, Washington DC, February 2003) <https://www.sec.gov/rules/final/ia-2106.htm\#P43_3923> accessed 28 June 2020.

US Securities and Exchange Commission, 'Roundtable on Proxy Voting Mechanics' (Topic on Share Ownership and Voting, Washington DC, May 2007) <www.sec.gov/spotlight/proxyprocess/proxyvotingbrief.htm> accessed 27 November 2019.

US Securities and Exchange Commission, 'Roundtable on the Proxy Process' (Chairman Jay Clayton cautions the participants about potential changes to the existing securities trading and clearing system, Washington DC, November 2018) <www.sec.gov/spotlight/proxyprocess/proxyvotingbrief.htm> accessed 27 November 2019.

Van der Elst, C and Lafarre A, 'Blockchain and Smart Contracting for the Shareholder Community’ (2019) 20 European Business Organization Law Review <https://link.springer.com/content/pdf/10.1007\%2Fs40804-019-00136-0.pdf> accessed 27 November 2019.

Wyman O, 'Blockchain in Capital Markets: The Prize and the Journey' (Joint Report with Euroclear, February 2016).

Yermack D, 'Corporate Governance and Blockchains’ (2017) Oxford University Press Review of Finance 7. Zhao C, 'CZ on Centralization Vs. Decentralization' (Binance Blog, 12 February 2019) $<$ www.binance.com/en/blog/301982828007075840/CZ-on-Centralization-VsDecentralization?ref=tokendaily> accessed 29 November 2019. 